\title{
Wage Arrears and the Distribution of Earnings in Russia
}

\author{
By: Hartmut Lehmann and Jonathan Wadsworth
}

William Davidson Working Paper Number 421

December 2001 


\title{
Wage Arrears and the Distribution of Earnings in Russia
}

\author{
Hartmut Lehmann ${ }^{1}$ and Jonathan Wadsworth ${ }^{2}$
}

\author{
This version: December 2001
}

1. Heriot-Watt University, Edinburgh; IZA, Bonn; and WDI, University of Michigan Business School

2. Royal Holloway College, University of London; Centre for Economic Performance, LSE; IZA, Bonn; and WDI, University of Michigan Business School jwadsworth@1se.ac.uk

Address for Correspondence:

School of Management

Heriot-Watt University

Edinburgh EH14 4AS

Tel: 00441314513626

Fax: 00441314513008

Email: h.lehmann@.hw.ac.uk

This paper took its inspiration from previous joint work with Ruslan Yemtsov, who has moved on to more important work at the World Bank.

The authors are grateful to John DiNardo and Jochen Kluve for making their STATA routines available; to Boris Augurzky, Todd Idson, Alan Manning, Mark Schaffer, Christoph Schmidt, Jan Svejnar, Paul Walsh, participants at the IZA-WDI Conference on Labour Markets in Transition Countries in May 2000 in Bonn, at the CEPR-WDI Conference on Transition in Moscow and at an ACES/Econometric Society session of the ASSA Conference in January 2001 in New Orleans as well as participants in seminars at the Universities of Heidelberg, Heriot-Watt University, the London School of Economics, the University of Trento and the WDI, University of Michigan for valuable comments. The Fritz Thyssen Foundation provided financial support within the project "Economic Reform and Labour Market Adjustment in the Russian Federation." The authors are also grateful to IZA for providing the facilities for the authors to undertake research on this paper. The opinions expressed are those of the authors and do not necessarily reflect those of the institutions with which the authors are affiliated. 


\begin{abstract}
The increase in wage inequality in Russia during its transition process has far exceeded the increase in wage dispersion observed in other European countries undergoing transition. Russia also has an extremely large incidence of wage arrears. We analyse to what extent wage arrears affect the wage distribution and measures of wage inequality in Russia. We present counterfactual distributions, derived from a variety of different methods, which suggest that conventional measures of earnings dispersion would be some 20 to 30 per cent lower in the absence of arrears. We then go on to show how wage gaps at various points in the pay distribution across gender, education, region and industry are influenced by a failure to allow for wage arrears. Using our counterfactual estimates we show, for example, that the median gender wage gap would be around twenty-five points higher than the actual gap that we observe. Similarly, the counterfactual ratio of mean graduate pay to mean pay of those with primary education is around twenty points lower than observed. We show that the parameters of the counterfactual wage distributions are very similar to the parameters of the observed wage distributions of those not in arrears. This means that for those wishing to study aspects of wage differentials and inequality in Russia, it may be feasible to use the subset of those not in arrears and still get close to the true population parameters.
\end{abstract}

JEL Classification No.: J6

Key Words: Wage Arrears, Earnings Inequality, Counterfactuals, Transition Economies, Russia 
William Davidson Institute Working Paper 421

\section{Wage Arrears and the Distribution of Earnings in Russia}

\section{Hartmut Lehmann and Jonathan Wadsworth}

\section{Introduction.}

Wage inequality in Russia following the end of central planning has risen far more than in Central and Eastern European (CEE) countries undergoing transition. According to estimates based on official statistics, the Gini coefficient for wages in Russia rose from 0.22 before transition to around 0.5 in 1996 and the 90:10 income decile ratio tripled from 3.3 before transition to 10 in 1995 (Flemming and Micklewright, 1997). In contrast, over the same period, the estimated Gini index for wages in CEE grew from levels in the range of 0.2 to 0.25 to levels in the range 0.3 to 0.35 . The level of wage inequality in Russia is now also very high by

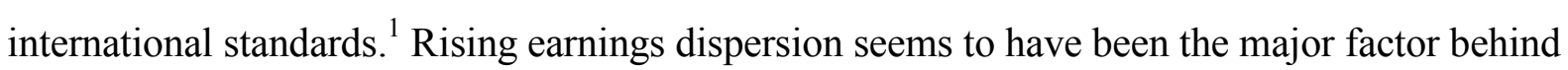
rising inequality in personal incomes.

All these trends are now well documented in the literature. But the reasons for (a) the sharp increase in earnings inequality in Russia and (b) the divergence between Russia and Central and Eastern Europe, are not entirely clear. Why was the rise less pronounced in the advanced reformer-countries compared to a country lagging in economic reforms, and not the opposite, as the logic of emerging returns to market oriented skills would suggest? There is little evidence of any large earnings discrepancies in aggregate data between industries. A majority of Russian workers are still employed in state-owned enterprises (SOEs) or the government, and therefore still subject, at least in theory, to regulated normative wages, under the "tariff ladder". The evidence presented in Brainerd (1998) also suggests that whilst returns to education, if not experience, have grown over the period, they remain low by Western standards. As such these factors cannot explain the extent of inequality observed in Russia.

1 In Chile, the Gini coefficient is around 0.45 and in Turkey around 0.37 . 


\section{William Davidson Institute Working Paper 421}

One simple explanation of growing inequality in the wage distribution could be the presence of wage arrears. If in any given month a substantial subset of workers, receive only a part of the normal wage, or even no wage at all, then inequality in wages in any given month will be extremely high. However, the timing of the dramatic rise in inequality during the first years of transition documented in Brainerd (1998) indicates to us that most of the rise in inequality occurred before the problem of wage arrears really began. Hyperinflation at the onset of reforms is probably the major contributing factor to the rise in inequality at this time, however, as inflation subsided inequality has not fallen back. It, therefore, seems important to try to analyse to what extent wage arrears have affected the earnings distribution since payment problems began.

Wage arrears have been a pervasive feature of Russian economic life since 1994 affecting large sections of the workforce (Lehmann, Wadsworth and Acquisti, 1999, show that this affects between 40 and 70 percent of the workforce). The withholding of wage payments has been systematic and concentrated heavily on sub-sections of the working population (see e.g. Earle and Sabirianova, 2002, and Lehmann, Wadsworth and Acquisti, 1999). An explicit treatment of distributional effects of wage arrears has, however, not yet been undertaken. 2 Most studies of wages in Russia tend to ignore the presence of wage arrears without considering the possible consequences. Using Russian Longitudinal Monitoring Survey (RLMS) data, covering the years 1994 through 1996 and 1998, we explore the issue of how wage arrears have affected the wage distribution and the level of wage inequality in Russia.

In order to demonstrate the effects of wage arrears on the wage distribution, Table 1 and Figure 1 give summary measures of the changes in real monthly wage distribution across our

2 Gimpelson (1998) discusses distributional issues connected to wage arrears from a political rather than an economic perspective. 


\section{William Davidson Institute Working Paper 421}

sample period. We also provide estimates from Poland and Britain as benchmark comparisons ${ }^{\text {B }}$. The Russian data suggest that, by 1998, around 70 percent of employees did not receive a wage complete and on time, and half of these received nothing in the preceding month. Whilst disturbing in itself, this finding of a large number of zero wage observations among the working population means that any conventional measures of inequality based around logarithmic transformations will be of little use here. In what follows therefore, we focus on the real monthly wage distributions and eschew any techniques that rely on logarithmic transformations.

Real average earnings fall markedly over the sample period prompted by a series of national economic crises which left inflation soaring and nominal wages failing to keep pace. The earnings distribution also widens over the first half of the sample period, while the evidence for the second half of the sample period is mixed. The coefficient of variation continues to increase, albeit more gently, but the Gini coefficient and the 90:50 ratio fall back. By 1996, the Gini coefficient in Russia was more than twice that observed in Poland and 60 percent higher than in Britain.

It is apparent, however, that the Russian results are strongly influenced by wage arrears. Figure 2 tracks the increased skewness of the real monthly wage distribution as the incidence of arrears builds up. The bottom panel of Table 1 confirms that inequality rises by much less amongst those who receive wages in full during the sample period. The Gini coefficient, for example, is roughly one third lower for those without wage arrears.

In some sense it is difficult to analyse wage distributions in Russia for this period since wage arrears scramble the distribution. Persons appear in low deciles solely because they are not paid at all or paid only part of their wages. So to analyse distributional issues seriously counterfactual wage distributions for years in which wage arrears are a problem seem to be

3 The figures for Poland are for full-time workers only, though, as in Russia, part-time working amounts to less than $3 \%$ of the Polish workforce. 


\section{William Davidson Institute Working Paper 421}

required.

In what follows, we try to estimate what the wage distribution would have looked like during this period if all workers had been paid in full and on time in order to establish the "true" parameters of the distribution and any between-group differences. As we argue in the next section there are several reasons for undertaking such an exercise. We use seven methods to construct counterfactual distributions. The first is a simple least squares prediction and the second is least squares with the addition of a random residual, both of which use parameters from a wage equation estimated on the sample without wage arrears to predict wages for those in arrears. The third is a Tobit II extension of the second method, which corrects for the incidental truncation of the wage distribution (Heckman correction). We then apply a different residual according to the method proposed by Juhn, Murphy Pierce (1993). We also provide counterfactual estimates of what the wage distribution would look like if everyone were paid on time following the Kernel density approach pioneered by DiNardo, Fortin and Lemieux (1996). Our sixth method employs a variation of the exact matching techniques used by, among others, Heckman, Ishimura and Todd (1997), and Kluve, Lehmann and Schmidt (1999), to assign wages to those in arrears by matching their characteristics to the sub-sample of those who continue to be paid in full but who had a similar labour market pre-treatment history. The last method matches on the propensity score (Lechner, 2000). These matching estimators, we suggest, may take account of unobserved heterogeneity that could be missed by the other approaches. Our results, similar across the various methods, suggest that most of the earnings dispersion in Russia occurs amongst the stock of workers affected by wage arrears, and that earnings dispersion may have been some 30 percent lower in the absence of arrears.

Having estimated these counterfactual distributions we then examine the implications for 


\section{William Davidson Institute Working Paper 421}

estimates of between-group wage differentials commonly addressed in the literature. One interesting application is a reassessment of the analysis of the gender wage gap. Much of the existing work on the Russian wages has ignored the presence of wage arrears. 4

However, given that, on average, women seem to be less affected by wage arrears (cf. Lehmann, Wadsworth and Acquisti, 1999) we would expect the mean gender gap to be larger with any of the counterfactual distributions than with the actual observed wages. This prior is confirmed by our analysis. We also can look at the gender gap sweeping through the entire earnings distribution, something we cannot do when wage arrears are present on a massive scale. In addition, we look at how wage arrears might affect returns to education and relative wage distributions by region and industry.

In the next section we look at the rationale for constructing counterfactual wage distributions in the Russian case. The subsequent section presents the various methods employed to construct counterfactual wage distributions, while section IV discusses data issues. Section V analyses earnings inequality in Russia and the decomposition of its change over time, followed by a presentation of the counterfactual results. Section VII then concludes.

\section{Economic Reality in Russia and the Construction of Counterfactual Wage Distributions}

The question might be raised why one would like to construct counterfactual wage distributions in Russia that assume payment of wages in full and on time for all employed members of the workforce. One could argue that during transition as labour hoarding continues the Russian economy is confronted with a macro constraint that makes it impossible to pay the contracted wage. Since mass layoffs are in the short-run politically and economically too costly $\frac{1}{5}$, the

\footnotetext{
4 Oglobin (2000) is an exception to this, using a selection equation in his analysis of the mean gender pay gap.

5 Russian labour market legislation stipulates severance pay of three monthly salaries for workers laid off in a mass layoff.
} 


\section{William Davidson Institute Working Paper 421}

Russian economy may then be intrinsically unable to honour all contractual wage claims in any given month. The practice of wage arrears then, is an economic policy tool that is consciously chosen by policy makers and managers to deal with output contraction in Russia. Equally, instead of, for example, imposing an inflationary tax on the entire workforce, the major costs of transition could be put on the shoulders of weak sub-groups of the workforce by withholding regular wage payments from them. Wage arrears are, therefore, an integral part of the labour market experience of many Russian workers. The upshot of these considerations then would be that the actual wage distribution is what matters and not some elusive counterfactual.

The above lines of reasoning do not preclude, in our opinion, the construction of counterfactual wage distributions, for the following reasons. First, if wage arrears are brought about because of a conscious policy of avoiding mass layoffs or a reluctance to use a general inflationary tax, then we can think of counterfactual wage distributions as reflecting a counterfactual economic policy that encourages the release of labour from unproductive, declining sectors. Such a policy, which has been used in most countries of Central and Eastern Europe despite large initial falls in output, seems to avoid inflationary bottlenecks and reverses the output decline. If such a counterfactual economic policy had been chosen those in work would almost certainly get paid in full and on time ${ }^{6}$.

Secondly, even if there is no conscious attempt by policy makers and managers to concentrate the costs of transition on some sub-groups of the workforce, there is no reason to assume that the "non-payment equilibrium" (Earle and Sabirianova, 2000) is the only natural, rational outcome that had to arise in the Russian labour market during transition. In this case

6 It may be that there would be differential unemployment levels across the two scenarios. The manner in which unemployment affects the parameters of the wage distribution in Russia is however unclear. The evidence on wage arrears emerging from the analysis in this paper suggests that wage arrears are distributed rather randomly across the wage distribution.

7 Desai and Idson (2000) seem to assume this non-payment equilibrium as the natural outcome in the Russian 


\section{William Davidson Institute Working Paper 421}

wage arrears occur because of some constraints that are not exogenous. The political constraint that does not allow mass layoffs could have been relaxed as could have been labour market legislation that imposes too large costs on firms in connection with these layoffs. One could even envisage the counterfactual as that which would emerge in the absence of large shocks. In summary, as long as we can think of sensible counterfactual policy regimes or scenarios it seems legitimate to construct counterfactual wage distributions.

When we construct counterfactual wage distributions in Russia we make, however, the assumption that there are no job losses when all workers get paid in full. Linking thus constructed counterfactual wage distributions to counterfactual policy regimes, we in essence presume a bargaining situation where workers are all-powerful and capable of shifting the entire burden of adjustment onto the enterprise. However, Russian workers are poorly organised and unions are weak, so the extreme assumption of no trade-off between elimination of wage arrears and employment is highly unrealistic. Constructing counterfactual wage distributions that take this trade-off into account is, on the other hand, very difficult as we have no estimates of the elasticity of employment with respect to wage arrears.

If wage arrears are, however, a problem of irregular pay and not of permanently withheld wages, then we have a strong rationale for constructing counterfactual wage distributions that ignore the trade-off between the elimination of wage arrears and employment. Evidence on the dynamic nature of the arrears process provides this strong rationale for the use of such counterfactual densities. Aggregate data from Russian Statistical Office (Goskomstat) tell us that since 1996 the stock of wage arrears has been approximately in a steady state, equivalent to two monthly wage bills. This means that the amount of contractual wages not paid to (some) workers

transition period

8 In the Western context, Svejnar (1986) shows such outcomes of the wage bargain when workers are all powerful. 


\section{William Davidson Institute Working Paper 421}

in month $\mathrm{t}$ roughly equals to the amount of wage debts paid back to (some) workers in month $\mathrm{t}$. This implies that even though wage arrears are not a purely stochastic phenomenon in the sense that incidence is not random, most of the workers affected by them do get paid the owed wages eventually. The RLMS provides a monthly data window as far as wage payments are concerned. This monthly window might then be too narrow to obtain an estimate of the "permanent" earnings of those workers affected by the irregularity of pay. 10 However, issues dealing with the distribution of earnings like the gender gap or returns to human capital should be investigated using estimates of "permanent" earnings. The counterfactual distributions constructed by us provide estimates of such "permanent" earnings, albeit imperfect ones.

\section{Building Counterfactual Estimates of the Effects of Wage Arrears}

Counterfactual wage distributions have been applied to a variety of economic and statistical issues, e.g. minimum wages (DiNardo, Fortin and Lemieux ,1996), item non-response (Biewen, 1999) and international differences in wage inequality (Blau and Kahn, 1996). The literature suggests at least 7 ways of building counterfactuals.

\section{OLS methods}

Following Oaxaca (1973) we can estimate a wage equation using the sample of those without

\footnotetext{
9 Payroll data from the city of Ryazan' recently collected by one of us also seem to confirm this pattern.

10 Consider a simple thought experiment. Assume an economy where all workers get paid monthly. Let us make the additional assumption that the data window on earnings is the third week of the month in which we undertake the survey. So, we ask: "How much did you get paid in the third week of month x?" Some workers will have been paid their monthly salary in this third week, but many will have been paid in another week of month x. Estimation of monthly earnings on this weekly window will be certainly inefficient, or even misleading. If, in the Russian case, we had a window of, say, two, three or four months, we could obtain better estimates of "permanent" earnings of Russian workers. The construction of counterfactuals is a good substitute for such estimates.

11 They give imperfect estimates of "permanent" income since the counterfactuals ignore the losses in earnings over time due to inflation. One should recall, though, that wage arrears are particularly virulent in times of low inflation (Gimpelson, 1998).
} 


\section{William Davidson Institute Working Paper 421}

wage arrears. Using the vector of estimated parameters from the no arrears equation and the observed characteristics of those in arrears we then predict wages, which those in arrears would have received if they had been paid in full. More formally, let $\mathrm{B}_{\mathrm{NW}}$ be the vector of parameter estimates from the wage equation of the sample without wage arrears and let $\mathrm{X}_{\mathrm{i}, \mathrm{WA}}$ be a vector of characteristics of the i-th person who experiences arrears. Then the predicted wage of this individual, $\mathrm{Y}_{\mathrm{i}, \mathrm{wA}}$, will simply be:

$$
\mathrm{Y}_{\mathrm{i}, \mathrm{WA}}=\mathrm{B}^{\prime}{ }_{\mathrm{NW}} \mathrm{X}_{\mathrm{i}, \mathrm{WA}}
$$

Since this method gives only a mean prediction, we can add a residual so as to proxy wage dispersion in full, since the actual wage equals the sum of the predicted wage and a residual, $\mathrm{W}=w+u$. We do this by first taking the standard error of the regression from the no arrears equation, $\sigma_{\mathrm{NW}}$, and multiplying by a, randomly assigned, standard normal random variable $\mathrm{z}_{\mathrm{i}}$. It follows that a random residual which can be added to the predicted wage for the arrears subgroup then is given by

$$
\varepsilon_{\mathrm{iWA}}=\mathrm{z}_{\mathrm{i}} * \sigma_{\mathrm{NW}}
$$

\section{Heckman Selection Model}

If there is any incidental truncation of the wage distribution in case of wage arrears then the coefficients used in equation (1) are not consistent if unobserved factors that determine the level of wages are correlated with unobserved forces driving the incidence of wage arrears. In order to achieve consistent estimates of the $\mathrm{B}_{\mathrm{NW}}$ vector we estimate a Tobit II variant of Heckman's selection correction model, where the parameters of the selection equation are assumed to be different from the parameters entering the wage equation. Such an assumption seems reasonable as the effect of most regressors on the level of wages should be different from their effect on the 


\section{William Davidson Institute Working Paper 421}

probability of experiencing wage arrears. The Tobit II model is estimated using Maximum Likelihood. The main difficulty in this estimation is to find a regressor that identifies the model, as it is hard to think of factors that determine the probability of experiencing wage arrears but not the level of wages. Drawing on previous results from our research on the Russian labour market we use a rural/urban dummy as an identifier in the selection equations, (Lehmann, Wadsworth and Acquisti, 1999). We take the estimated coefficients of the no arrears group in the presence of the selectivity term, apply them to the characteristics of the arrears group and add a random residual. However, it seems clear to us that the results of the Tobit II model are extremely sensitive to specification and that alternative methods of constructing counterfactual wage distributions need to be also explored.

\section{Juhn, Murphy and Pierce}

Juhn, Murphy and Pierce (1993) and Blau and Kahn (1996) have suggested that it may be worthwhile trying to take into account unobserved heterogeneity as measured by the percentile ranking of each individual in the residual wage distribution. With a simple transformation of the residual into the product of a standard normal residual, $\theta$, and the residual standard deviation from the wage equation, $\sigma$, the predicted wage can be written as

$$
\mathrm{Y}_{\mathrm{i}, \mathrm{WA}}=\mathrm{B}_{\mathrm{NW}} \mathrm{X}_{\mathrm{i}, \mathrm{WA}}+\sigma_{\mathrm{NW}} \theta_{\mathrm{WA}}
$$

So that the counterfactual is the set of wages that would result if the no arrears wage coefficients and residual standard deviation were given to those currently in arrears. The estimates from the equations used to construct these estimates are given in Table A1 in the Appendix. It is apparent that the estimated coefficients vary widely between the arrears and no-arrears groups. Since many of the observations on the dependent variable in the arrears sample are zero, this technique relies on the assumption of normality in the residuals estimated from this subset. $\frac{12}{12}$

12 This is not always the case in our data. 


\section{Kernel Density Counterfactuals}

DiNardo, Fortin and Lemieux (1996), (hereafter DFL), have suggested that a broader insight may be obtained by taking into account the entire wage structure, allowing the returns to observables and unobservables to vary across the distribution of wages. The principal remains the same, to estimate the wages that those in arrears would receive had they been paid as those paid in full. Given the joint distribution of wages, w, and characteristics, $\mathrm{x}$, the marginal distribution of wages conditional on $\mathrm{x}$ can be written $\mathrm{g}(\mathrm{w})=\int f(w / x) h(x) d x$. The conditional expectation, $\mathrm{f}(\mathrm{)})$ is similar to an estimated regression line and the marginal density of $\mathrm{x}, \mathrm{h}(\mathrm{)})$ is analogous to the vector of characteristics. Following DFL, using Bayes' law, it can be shown that the counterfactual wage distribution if everybody were paid in full can be obtained by taking the observed wage distribution of the subset of those paid in full and reweighting by a parameter $\Phi(\mathrm{x})$, where $\Phi(\mathrm{x})$ reflects the relative incidence of arrears conditional on characteristics x, $\Phi(\mathrm{x})=\operatorname{Pr}($ No Arrears $) / \operatorname{Pr}($ No Arrears/x). The weights are normalised to sum to one. So,

$$
g(w)=\int \Phi(x) f^{\text {NoArrears }}(w / x) h(x / i=\text { NoArrears }) d x
$$

The integral is approximated using Kernel density estimation, which means that we do not get predictions of individual wages, only the quantiles of the distribution. The numerator in $\Phi(\mathrm{x})$ is the sample proportion of those not in arrears in any year and the denominator is estimated by a logit regression conditional on a set of observed characteristics. The estimates from the logit equations used to construct these estimates (Table A2) confirm the dominance of location and firm characteristics in explaining the incidence of arrears as found in Lehmann, Wadsworth and Acquisti (1999).

\section{Matching Estimators}




\section{William Davidson Institute Working Paper 421}

If there were unobserved heterogeneity amongst those in arrears, then the preceding techniques would fail to account for this. The JMP approach and the DFL density approach perhaps come closest, the latter using the non-parametric structure of the entire distribution. However they implicitly assume that heterogeneity amongst those not in arrears is duplicated amongst those in arrears. If this is not the case, those not in arrears are different from those in arrears, the counterfactual estimates could be biased in some way. Moreover, the JMP method uses the standard residuals from the arrears regression to calculate counterfactuals. This standardised residual is usually interpreted as an individual's ranking in the residual wage distribution and as such a measure of unobserved relative skill. However, the outcome we analyse in equation (3) gives an individual's relative ranking in the residual arrears distribution, which is hard to interpret as a measure of unobserved skill. This, together with our wish to construct counterfactuals untainted by arrears leaves this method open to question.

We therefore experiment with alternative approaches based on the matching estimator literature. The first technique follows Heckman, Ishimura and Todd (1997) in that we also condition, non-parametrically, on "pre-treatment history" in order to minimise biases arising from unobserved heterogeneity. In our case this means conditioning on events before wage arrears began, together with a set of current observable, exogenous characteristics, in order to try and capture heterogeneity in the arrears population, i.e. to ensure that the treatment and the control group do not differ systematically. Conditioning on a set of pre-treatment covariates is assumed to be sufficient to allow the assumption of assignment to the treatment group as random, such that unobservables may be ignored. If $\mathrm{Y}_{\mathrm{i} 1}$ is the outcome with treatment and $\mathrm{Y}_{\mathrm{i} 0}$ is the outcome without treatment for individual $\mathrm{i}$ and $\mathrm{X}$ and $\mathrm{H}$ are sets of controls for observable characteristics and "pre-treatment history", then the identification assumption becomes, 


\section{William Davidson Institute Working Paper 421}

$\mathrm{E}\left(\mathrm{Y}_{\mathrm{i} 0} / \mathrm{T}=1, \mathrm{X}, \mathrm{H}\right)=\mathrm{E}\left(\mathrm{Y}_{\mathrm{i} 0} / \mathrm{T}=0, \mathrm{X}, \mathrm{H}\right)$. Heckman, Ishimura and Todd (1997) find that for this type of matching estimators to work well the same data set should be used for the control and treatment group, the groups should be in the same local labour markets and the data set should contain a rich set of variables relevant to the treatment decision.

Treatment in our study is the experience of wage arrears and the labour market history we condition on, using the panel element of the RLMS, is labour market status one year earlier and if employed, the ranking in the wage distribution of those paid in full. If the individual was out of work one year earlier we create unemployed and inactive categories. If the individual was in arrears one year earlier we create a separate sub-category. We divide last year's wage distribution, excluding arrears, into deciles. Matching proceeds for those sub-groups of the treated and the non-treated who have the same "pre-treatment history", and in addition we match according to age (with a maximum allowed difference of ten years), gender, region (3 groups) and qualifications (6 groups) in the current year. This strategy conforms broadly to the criteria set out by Heckman et al. (1997) required for a good performance of a matching estimator. Also, the assumption here is that the variables used for matching are not affected by the treatment (arrears).

We assign the wages of those currently paid in full to those in the treatment group, who were placed in the same decile a year ago when both treatment and control groups were paid in full. Those in arrears now who were also in arrears last year or non-employed are given the wages of those currently paid in full who were in the same category one year earlier. In this way, we hope to reduce the difference in unobserved skills and other characteristics that might exist between the individuals experiencing wage arrears and those who are unaffected by them. If more than one person can be matched with the individual we assign the average wage of the

13 Whilst within region mobility may be affected by arrears, the regions in the RLMS are so large as to make mobility between regions as a result of arrears unlikely. 


\section{William Davidson Institute Working Paper 421}

matched controls. With this direct matching procedure the set of variables used is much smaller than can be afforded by a regression based technique which is unaffected by empty cells. The matching algorithm is shown in Box A1 in the appendix.

The approach assumes that individuals do not move rapidly through the earnings distribution. As a check, Table A3 in the appendix presents one and four-year earnings transition matrices using quintiles of the wage distribution. It is apparent that, whilst there is a degree of mobility across earnings quintiles, there is considerably less mobility amongst those not subject to wage arrears. Figure 3 also suggests that those in arrears are drawn from across the entire wage distribution. Since this approach can only be used when there are at least two consecutive years of longitudinal data, we confine our estimates using this approach to 1996 and provide comparable estimates using the other counterfactual techniques.

\section{Propensity Scores}

When performing non-parametric matching we lose around 10 per cent of potential matches due to empty cells. To avoid this, we also employ propensity score matching, where individuals are matched according to the closeness in the estimated probability of experiencing wage arrears. We use the matching algorithm suggested by Dehejia and Wahba (1998). ${ }^{14} \mathrm{We}$ estimate probit regressions, conditional on the same co-variates as used in the matching approach, take the predicted probability - the propensity score - and match, with replacement, those in arrears with those not in arrears with the nearest propensity score. It can be shown that

14 As Kluve, Lehmann and Schmidt (2001) state, "the reduced dimension comes at a cost, however. The propensity score is not known and has to be estimated. Also, in samples of limited size, for some $i$ and $j$ it may occur that $p\left(X_{i}\right)=p\left(X_{j}\right)$ even if $X_{i} \neq X_{j}$, resulting in imperfect balancing of the distributions of covariates." The literature stresses that there seems to be a bias vs. efficiency trade-off between non-parametric and propensity score matching. Smith and Todd (2001) show that estimates from different propensity score matching methods do not vary much as long as the conditioning variables satisfy the requirements set out by Heckman et al. (1997). 


\section{William Davidson Institute Working Paper 421}

if $\mathrm{Y}_{\mathrm{i} 1}$ and $\mathrm{Y}_{\mathrm{i} 0}$ are independent of treatment, $\mathrm{T}$, given $\mathrm{X}$ and $\mathrm{H}$ (that is, given sufficient disaggregation by age, sex and region, for example, as well as by "pre-treatment history"), then the two groups may be treated as the same. In other words, $\mathrm{T}$ is ignorable given $\mathrm{X}$ and $\mathrm{H}$, so that $\mathrm{E}\left(\mathrm{Y}_{\mathrm{i} 0} / \mathrm{T}=1, \mathrm{P}(\mathrm{X}, \mathrm{H})\right)=\mathrm{E}\left(\mathrm{Y}_{\mathrm{i} 0} / \mathrm{T}=0, \mathrm{P}(\mathrm{X}, \mathrm{H})\right)=\mathrm{E}\left(\mathrm{Y}_{\mathrm{i} 0} / \mathrm{P}(\mathrm{X}, \mathrm{H})\right)$. We estimate two variants of the propensity score, one where pre-treatment variables are included in the set of covariates and one without them. In the latter case the identification assumption becomes,

$$
\mathrm{E}\left(\mathrm{Y}_{\mathrm{i} 0} / \mathrm{T}=1, \mathrm{P}(\mathrm{X})\right)=\mathrm{E}\left(\mathrm{Y}_{\mathrm{i} 0} / \mathrm{T}=0, \mathrm{P}(\mathrm{X})\right)=\mathrm{E}\left(\mathrm{Y}_{\mathrm{i} 0} / \mathrm{P}(\mathrm{X})\right)
$$

\section{Data.}

Our main data source is the second phase of the Russian Longitudinal Monitor Survey, (RLMS), a longitudinal panel of around 4000 households across the Russian federation conducted in the autumn of 1994, 1995, 1996 and 1998. The data contains a set of demographic and establishment characteristics, together with information on the labour market activities of its sample. Despite its relatively small size, the advantage of this source for our purposes, is that we can track individual wages and the incidence of wage arrears over time. We restrict our sample to employees of working age and exclude the military. ${ }^{15}$ The survey design does not follow individuals if they move, but does sample new occupants of the same address. There are around 10,000 individual observations in each wave, of which around 4000 are in work in any wave and around 3,500 give wage related information.

The survey questions dealing with wage arrears ask whether, conditional on being in work, an individual was owed money by the firm in the past month or was paid "in kind" with goods produced by the firm. This constitutes our sample of those in arrears in any wave. Some

15 The RLMS is ambiguous on the nature of self-employment, referring instead to the extent of self-ownership in the enterprise where the individual works. We exclude only those who say they own between 51 and $100 \%$ of the enterprise. 


\section{William Davidson Institute Working Paper 421}

of those in arrears are paid a certain amount of money, whilst others, around one half of those in arrears, receive nothing. ${ }^{16}$ Respondents, both those paid in full and those in arrears, are asked to state the amount of money received from their employers after tax in the past month. These are total wage receipts and not contractual wages. There is no distinction made between basic wages and bonus. These wage responses are then deflated by a national price deflator indexed to 100 at January 1998. ${ }^{7}$ There is no indication whether wage arrears are estimated before or after tax. We remove outliers from that data, namely those earning in excess of 4000 roubles a month, or less than 50 roubles if the respondents are not in arrears.

We also provide some data from a smaller, household survey data set, VTsIOM, undertaken in 1993 in order to provide summary evidence on pay from an earlier period when wage arrears were less prevalent.

\section{Earnings Distributions and Inequality in Russia}

Table 2 provides a formal decomposition of changes in earnings inequality over the period into its between and within-group components. 18 Following Cowell (1995) we can decompose any generalised entropy measure of inequality

$$
\mathrm{I}_{\mathrm{a}}=\mathrm{I}_{\text {between }}+\mathrm{I}_{\text {within }}
$$

where

16 The RLMS also asks for the total amount owed, together with the number of months since the worker was paid last.

17 There are no population weights in the data sets.

18 Fields' (2001) decomposition of the sources of wage inequality relies on a decomposition of the log variance of earnings, which is inappropriate here given the large number of zero wage observations.

19 Note that this approach calculates the between group component assuming that everyone within a group receives mean income, which is clearly not the case in Russia 
$\mathrm{I}_{\text {between }}=\frac{1}{\theta^{2}-\theta}\left[\sum_{j=1}^{k} f_{j}\left[\frac{\overline{y_{j}}}{\bar{y}}\right]^{\theta}-1\right]$

and

$\mathrm{I}_{\mathrm{within}}=\sum_{j=1}^{k} w j I j \quad$ where $\quad w j={ }_{g j}^{\theta} f_{j}^{1-\theta}$

and $\mathrm{f}_{\mathrm{j}}$ is the population share of group $\mathrm{j}$ and $\mathrm{g}_{\mathrm{j}}$ is the share of group $\mathrm{j}$ in total income $=f_{i} y_{i} / \bar{y}$.

So total within group inequality is a weighted average of inequality in each sub group, though the weights do not add to one unless $\theta=1$ or 0 . This decomposition is sensitive to the choice of parameter $\theta$, so in Table 2 we present estimates based on two different $\theta$ values. The results suggest that differences between those in arrears and those not accounts for around 20 to 30 percent of the rise in inequality between 1994 and 1996. The majority of the rise in inequality however comes from within the group in arrears. The results are more ambiguous over the second half of the sample period. Inequality rises or falls depending on the value of $\theta$ used, as do the within and between group components. The entropy estimate based on the low $\theta$ value falls between 1996 and 1998 most likely because low values put more weight on distances between wages in lower parts of the distribution and the share of those paid zero wages falls. This is not reflected in the other entropy estimate, which rises as it gives greater weight to wage changes in the upper tail. It remains true however that the majority of earnings inequality in any one period comes from amongst those in arrears.

Table 3 gives the results using the first four estimation approaches and the propensity score matching estimation without conditioning on pre-treatment history for the years 1994, 1996 and 1998. Figure 4 graphs the counterfactual Kernel densities. Not surprisingly the mean and 


\section{William Davidson Institute Working Paper 421}

various centiles of the distributions are all higher using the counterfactual estimates. Mean earnings rise by around 30\% in 1994 and between 50\% and 70\% when wage arrears were highest in 1998. Similarly estimated overall dispersion, as measured by the coefficient of variation, is between $23 \%$ and 36\% lower in 1994 and between $29 \%$ and $46 \%$ lower in 1998 . The Gini coefficients are now in the same range as those of Britain. The estimates of the various wage centiles show a narrower distribution when based on simple OLS predictions (OLS I) and the propensity score matching estimator than the estimates based on other methods. Since simple OLS estimation performs a regression to the mean, it comes as no surprise that the OLS I based earnings counterfactual distribution is narrower; it this feature of OLS estimation that provides actually a justification for the addition of a random error term. The larger 9-to-1 and 5-to-1 decile ratios for the OLS II and Heckit estimates can be explained by the skewness of the wage distribution. Adding a random normal residual to the predicted value will then generate too many negative values for predicted wages, giving a very low value for the 10-th percentile.

Table 4 uses the panel element of the data in order to add the exact matching estimator and a second propensity score estimator with "pre-treatment history" included as an additional regressor. We compare the results with those using the other methods for the year 1996. We also show the distribution of those in the sample who get paid in full and on time (second column). Apart from the estimates based on simple OLS prediction (OLS I) all other counterfactual distributions have a very similar spread as can be seen from the close coefficients of variation and the GINI coefficients. The distribution of the propensity score estimates seems to depend on the set of covariates used to generate the propensity scores. It also noteworthy that the no arrears distribution differs little from the counterfactuals, a point to which we will return later.

We now examine the implications of these counterfactual estimates for pay gaps between 


\section{William Davidson Institute Working Paper 421}

various sub-groups of the workforce. In Table 5 we compare levels and ratios of pay across gender using the actual distribution, the no arrears distribution and the counterfactual distributions for the year 1996. If everyone were paid in full, then there would be more dispersion in pay between men and women. If we exclude the propensity score estimates, the mean gender wage gap rises from the observed 19 percentage points to between 28 and 32 percentage points when counterfactual distributions are used. Also noteworthy is the fact that five of the counterfactual distributions show the largest wage gap at the tenth percentile, while in Western economies the widest divergence between male and female earnings usually occurs at the ninth decile. The no-arrears distribution gives mean and median ratios that are very similar to the levels of all but the propensity score based counterfactuals. On the other hand, the no-arrears distribution shows no variation of the ratios across deciles, which does not hold for any of the counterfactuals.

Table 6 shows mean and medium wages of three educational categories (graduate, intermediate and primary) and presents mean and medium ratios relative to the low educational category using the actual, the no arrears and all counterfactual distributions. It is striking that the actual distribution suggests a higher relative return to graduate education than the counterfactual estimates, while there is little difference in the relative returns for the intermediate group. It is also noteworthy, that the ratios from the no arrears distribution are again quite similar to those from the counterfactual distributions.

We now turn to two dimensions that impact strongly on the incidence of wage arrears, region and industry. We divide the sample into three areas: those living in Moscow and St. Petersburg (Metro), where the incidence of wage arrears is low and wages are high; those living in the Urals region, where wage arrears are massive, but wages are highest; and those living in 


\section{William Davidson Institute Working Paper 421}

the rest of the country, where wages are lower and the incidence of wage arrears is high. The actual distribution gives a $25 \%$ higher mean wage gain from living in one of the metropolitan regions compared with the counterfactuals and, ignoring the propensity score estimates, understates the mean wage difference between Urals and other regions by $20 \%$ on average. For the median ratios these biases are even more pronounced (Table 7).

In Table 8 we aggregate industries into two sectors, production and services, with workers in the former more likely to experience wage arrears than in the latter. There are discernible differences between the ratios of the actual and the other distributions at the median and the $90^{\text {th }}$ percentile. The counterfactual distributions suggest that if everyone were paid in full, then there would be more dispersion in pay between production and service sectors. The production sector seems to be more affected by wage arrears than services resulting in an increase of roughly $30 \%$ points as one goes from the actual to the no arrears or the counterfactual distributions.

\section{Conclusions}

Russia now has one of the highest levels of wage inequality in the world. While wage arrears were not responsible for the large increase in inequality, the estimates in our paper suggest that they may have been partly responsible for the failure of inequality to fall back following the unanticipated price shocks in the first half of the nineties. The majority of earnings inequality is experienced within the population experiencing wage arrears at any point in time. The large share of employees who receive no wages in any one month renders many conventional estimates of inequality inoperable. Counterfactual estimates of the wage distribution in the absence of arrears indicate that average earnings would be some twenty to fifty percent higher, depending on the 


\section{William Davidson Institute Working Paper 421}

extent of arrears and that earnings dispersion would be lower by similar amounts if everyone were paid in full. This puts earnings inequality back towards levels of inequality currently experienced in Western countries like Britain and the United States.

On the basis of the counterfactual distributions we find higher gender wage gaps through most of the distributions, with the mean gap taking on values approximately 10 percentage points higher than the actual gap in the year 1996. In contrast, our estimates suggest that the relative return to graduate education would be compressed by around 15 percent if everybody were paid in full. Regional pay differentials would become more compressed and sectoral differentials would be widened in the absence of wage arrears.

One striking feature of our exercise is that the parameters of the counterfactual wage distributions are very similar to the parameters of the observed wage distributions of those not in arrears. While this does not mean that experience of wage arrears is a random event as confirmed by evidence in Earle and Sabirianova (2002) and Lehmann, Wadsworth and Acquisti (1999), it does suggest that those in wage arrears are drawn reasonably uniformly from throughout the wage distribution. For those wishing to study aspects of wage differentials and inequality in Russia, it may, therefore, be feasible to use the subset of those not in arrears and still get close to the true population parameters, subject to an efficiency loss. 


\section{William Davidson Institute Working Paper 421}

\section{References.}

Biewen, M., (1999) 'Item Non-Response and Inequality Measurement: Evidence from the German Earnings Distribution', University of Heidelberg, Economics Department Discussion Paper No. 295, March.

Blau, F. and Kahn, L. (1996), 'International Differences in Male Wage Inequality', Journal of Political Economy, vol. 104, no.4, 791-836.

Brainerd, Elizabeth (1998), "Winners and Losers in Russia's Economic Transition." American Economic Review 88, 5:1094-1116, December.

Cowell, F., (1995), Measuring Inequality, Phillip Allen, London.

Desai, P. and Idson, T. (2000), Work Without Wages: Russia's Nonpayment Crisis, MIT Press, Cambridge, Mass. and London.

DiNardo, J., Fortin, N. and Lemieux, T., (1996), 'Labour Market Institutions and the Distribution of Wages', 1979-1992, Econometrica

Dehejia, R. and Wahba, S., (1998), 'Propensity Score Matching Methods for Non-Experimental Causal Studies', NBER Working Paper No. 6829.

Earle J. and Sabirianova K. (2000), 'Equilibrium Wage Arrears: A Theoretical and Empirical Analysis of Institutional Lock-In.’ IZA Discussion Paper No. 196.

Earle J. and Sabirianova K. (2002), 'Understanding wage arrears in Russia. Journal of Labor Economics, forthcoming.

Fields, G.S., "Accounting for Income Inequality and Its Change: A New Method, with Application to the Distribution of Earnings in the United States." Ithaca, N.Y. : Cornell University, July 2001.

Flemming and Micklewright . Income distribution, economic systems and transition (EBRD 1997

Gimpelson, V. (1998), The Political Economy of Wage Arrears, Budapest, mimeo.

Juhn, C., Murphy, K. and Pierce, B., (1993), 'Wage Inequality and the Rise in Returns to Skill', Journal of Political Economy, Vol. 101, No.3, pp. 410-42.

Kluve, J, Lehmann H. and Schmidt C., (1999), 'Active Labour Market Policies in Poland: Human Capital Enhancement, Stigmatization or Benefit Churning?', Journal of Comparative Economics, January, vol. 27, 61-89 
Kluve, J, Lehmann H. and Schmidt C., (2001), 'Disentangling Treatment Effects of Polish Active Labour Market Policies: Evidence from Matched Samples', IZA Discussion Paper No. 355 , September.

Lehmann, H. Wadsworth J. and Aquisti A. (1999). 'Grime and punishment: Job insecurity and wage arrears in the Russian Federation' Journal of Comparative Economics, December, vol. $27,595-617$

Oaxaca, R., (1973), 'Male-Female Earnings Differentials in Urban Labor Markets', International Economic Review, 14, 693-709.

Ogloblin C. G. (1999), 'The Gender Earnings Differential in the Russian Transition Economy', Industrial and Labor Relations Review, 52, 4, 602-627.

Smith, J.A. and Todd P.E. (2001), 'Reconciling Conflicting Evidence on the Performance of Propensity-Score Matching Methods', American Economic Review, vol. 91, no.2, 114-118. 
William Davidson Institute Working Paper 421

Figure 1. Real Wage Distribution 1994-98 (RLMS)

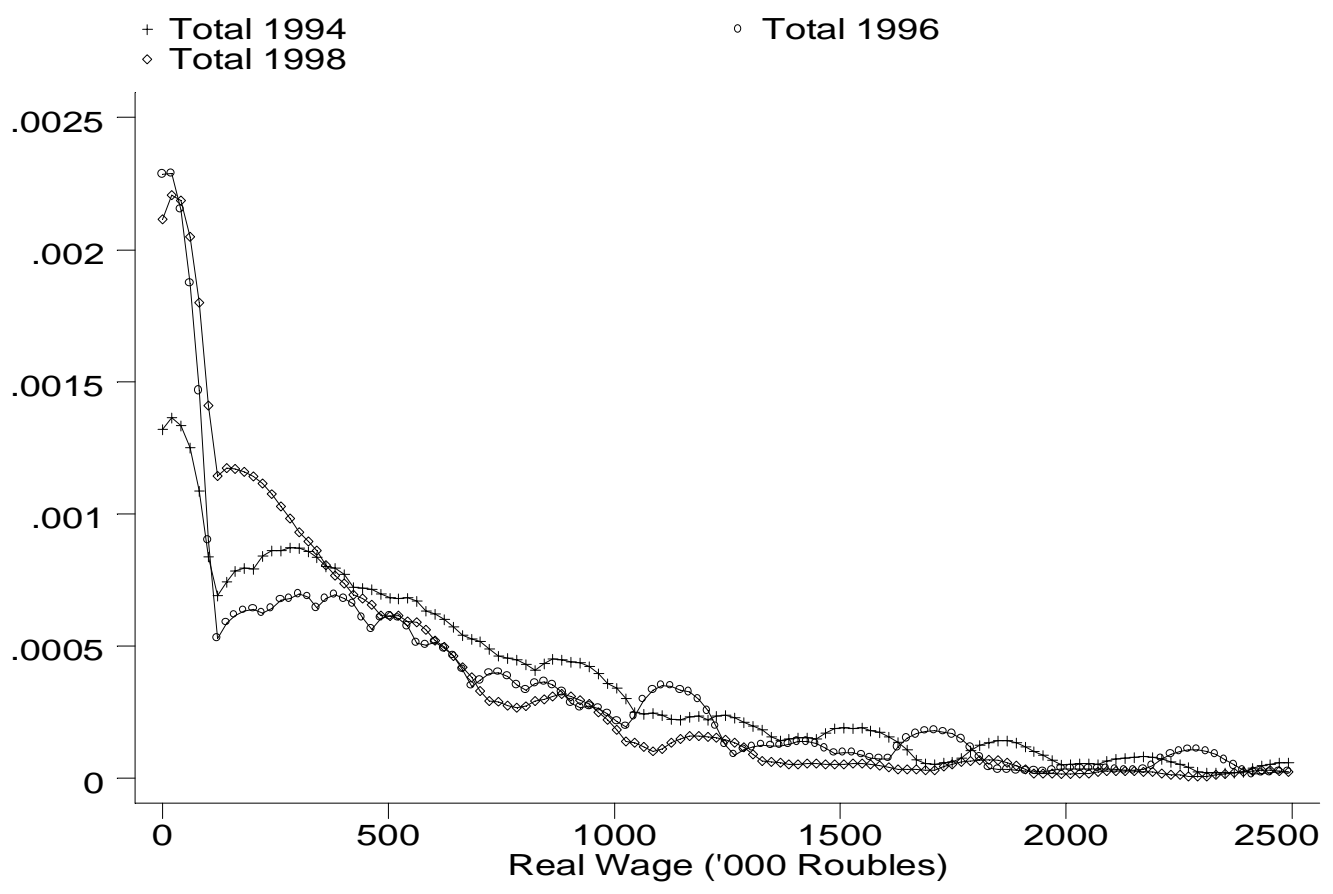


William Davidson Institute Working Paper 421

Figure 2. Distribution of Real Wages in Russia
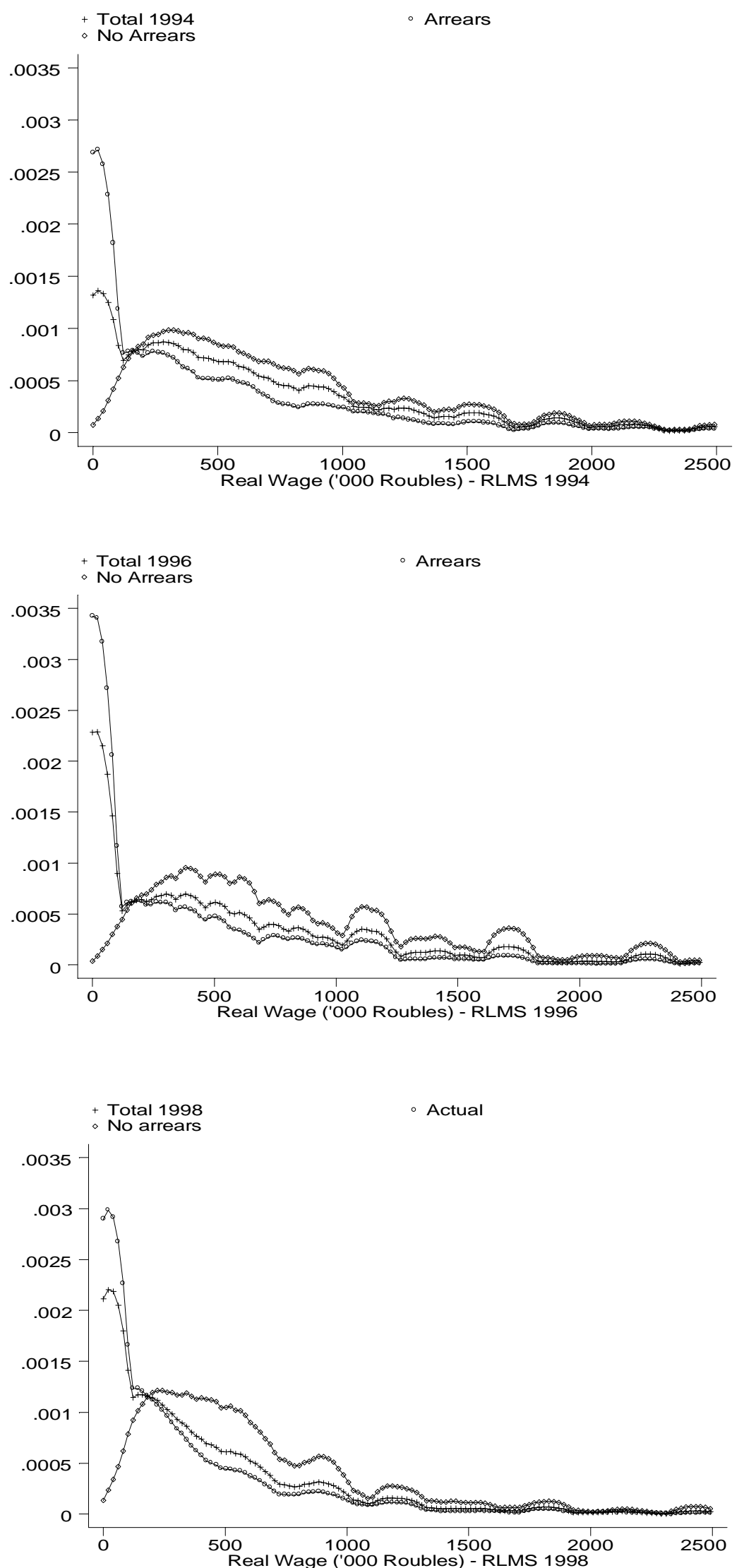
Figure 3. Decile Origin of Those in Wage Arrears
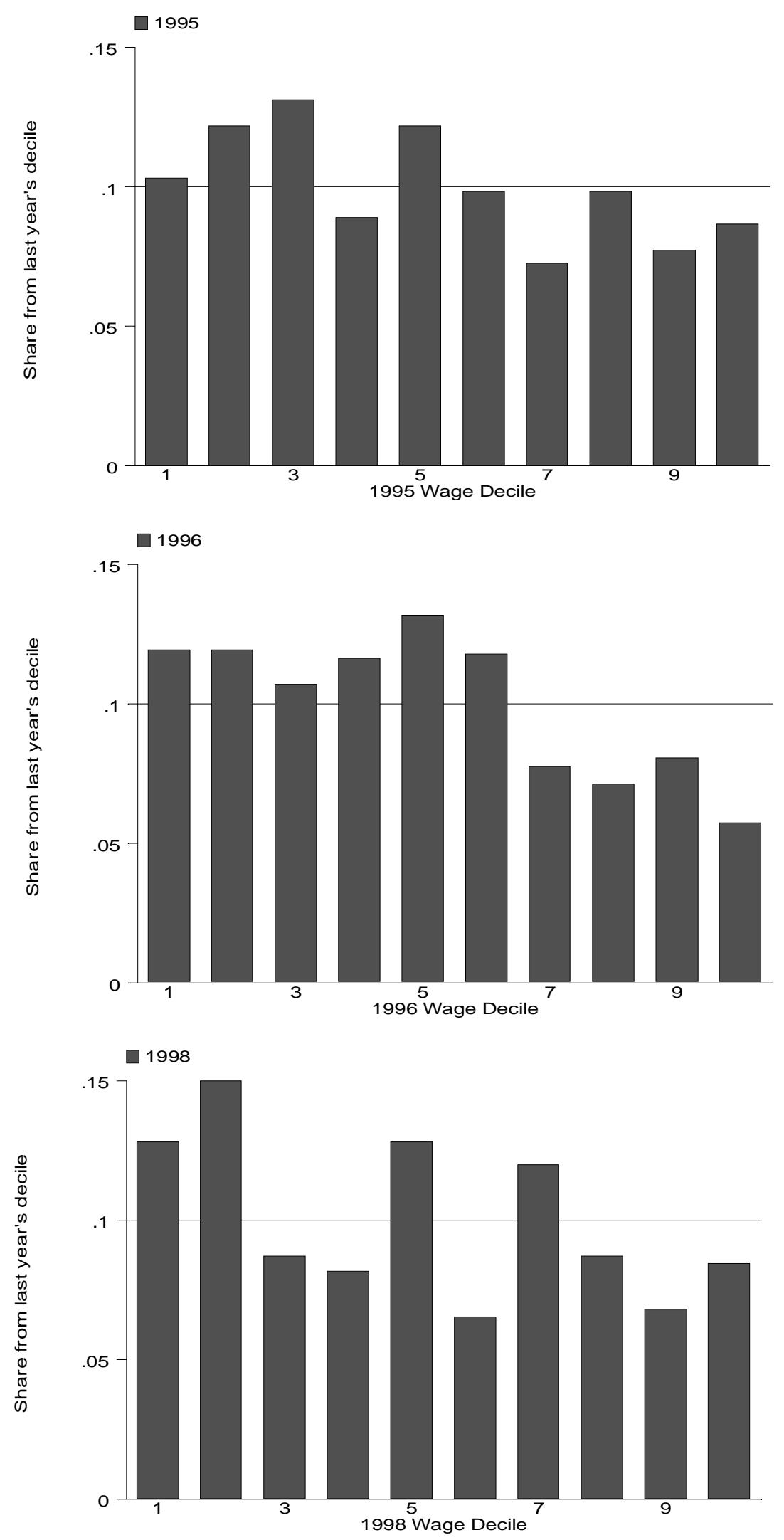
William Davidson Institute Working Paper 421

Figure 4. Counterfactual Estimates of Wage Distribution in Absence of Arrears
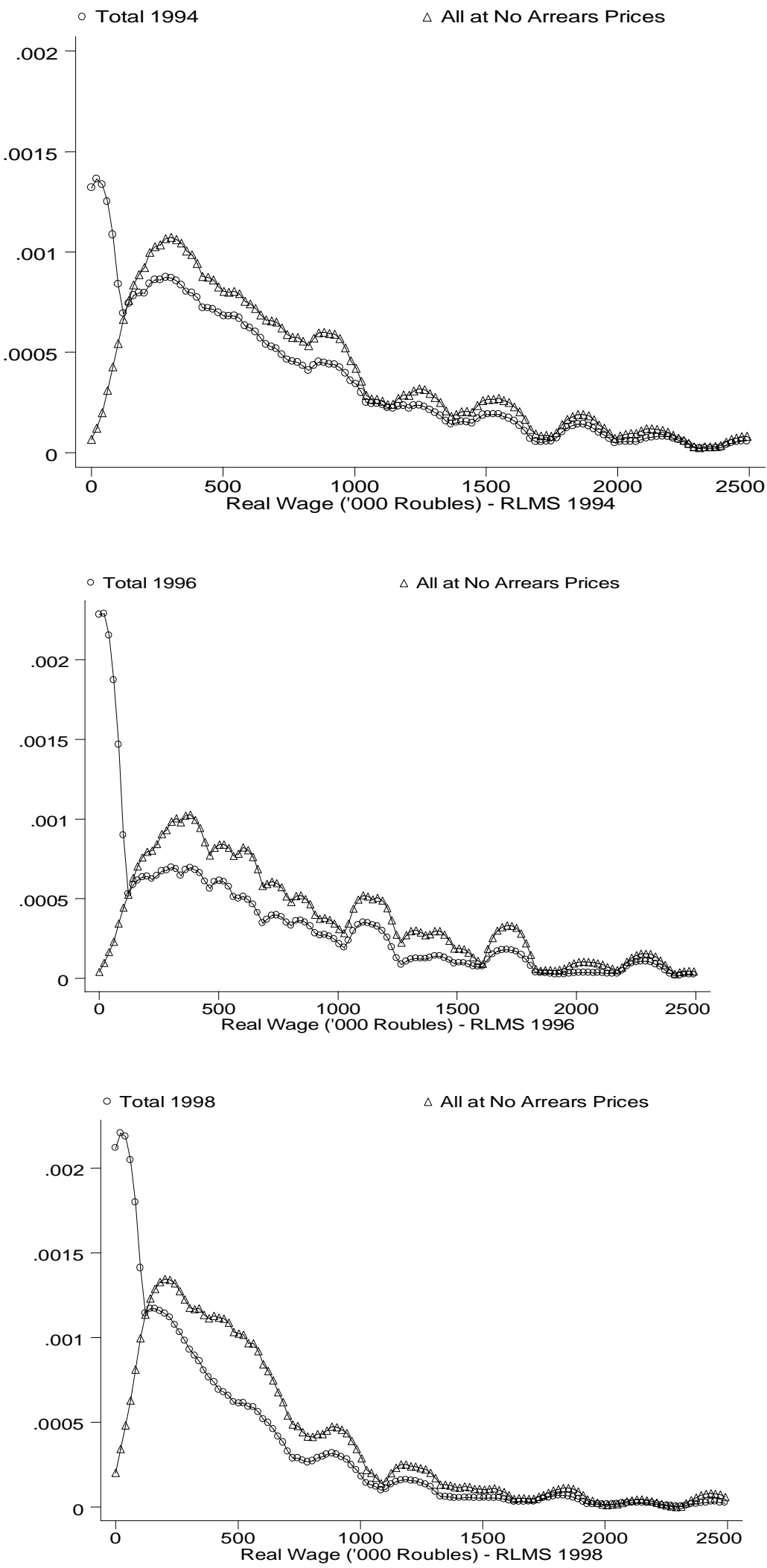
William Davidson Institute Working Paper 421

Table 1. Summary Measures of Real Monthly Wage Distribution

\begin{tabular}{|c|c|c|c|c|c|c|}
\hline & $\begin{array}{l}1993 \\
\text { VTsIOM }\end{array}$ & $\begin{array}{l}1994 \\
\text { RLMS }\end{array}$ & $\begin{array}{l}1996 \\
\text { RLMS }\end{array}$ & $\begin{array}{l}1998 \\
\text { RLMS }\end{array}$ & $\begin{array}{l}1996 \\
\text { Poland }\end{array}$ & $\begin{array}{l}1998 \\
\text { Britain }\end{array}$ \\
\hline \multicolumn{7}{|l|}{ Total } \\
\hline Mean & 930 & 867 & 547 & 396 & 140 & 1247 \\
\hline 90th & 1724 & 1563 & 1464 & 968 & 219 & 2316 \\
\hline 50th & 690 & 469 & 338 & 242 & 120 & 1054 \\
\hline 10th & 276 & 0 & 0 & 0 & 81 & 271 \\
\hline$\%$ no pay & 0.4 & 18 & 32 & 26 & 0 & 0 \\
\hline $90 / 10$ & 6.25 & $\mathrm{n} / \mathrm{a}$ & $\mathrm{n} / \mathrm{a}$ & $\mathrm{n} / \mathrm{a}$ & 2.70 & 8.55 \\
\hline $90 / 50$ & 2.5 & 3.33 & 4.33 & 4.00 & 1.83 & 2.20 \\
\hline $50 / 10$ & 2.5 & $\mathrm{n} / \mathrm{a}$ & $\mathrm{n} / \mathrm{a}$ & $\mathrm{n} / \mathrm{a}$ & 1.48 & 3.89 \\
\hline Coef. Var & 1.12 & 1.05 & 1.26 & 1.31 & 0.62 & 0.80 \\
\hline Gini & 0.410 & 0.535 & 0.622 & 0.613 & 0.239 & 0.387 \\
\hline$\%$ arrears & 9 & 49 & 66 & 72 & 0 & 0 \\
\hline \multicolumn{7}{|l|}{ No Arrears } \\
\hline Mean & 944 & 845 & 948 & 660 & & \\
\hline $90^{\text {th }}$ & 1724 & 1818 & 1989 & 1355 & & \\
\hline 50 th & 690 & 625 & 688 & 491 & & \\
\hline 10th & 276 & 200 & 229 & 166 & & \\
\hline $90 / 10$ & 6.25 & 9.09 & 8.69 & 8.16 & & \\
\hline $90 / 50$ & 2.5 & 2.91 & 2.89 & 2.75 & & \\
\hline $50 / 10$ & 2.5 & 3.13 & 3.00 & 2.96 & & \\
\hline Coef. Var & 1.12 & 0.80 & 0.79 & 0.85 & & \\
\hline Gini & 0.407 & 0.414 & 0.409 & 0.419 & & \\
\hline
\end{tabular}


William Davidson Institute Working Paper 421

Table 2. Between and Within Group Real Wage Inequality by Arrears

\begin{tabular}{|c|c|c|c|c|}
\hline & $\begin{array}{l}1993 \\
\text { VTsIOM }\end{array}$ & $\begin{array}{l}1994 \\
\text { RLMS }\end{array}$ & $\begin{array}{l}1996 \\
\text { RLMS }\end{array}$ & $\begin{array}{l}1998 \\
\text { RLMS }\end{array}$ \\
\hline Entropy $(\theta=0.5)$ & 0.298 & 0.660 & 0.979 & 0.900 \\
\hline within arrears & 0.003 & 0.435 & 0.731 & 0.715 \\
\hline$\left(\mathrm{w}_{\mathrm{i}}\right)$ & & $(.39)$ & $(.52)$ & $(.61)$ \\
\hline \multirow[t]{2}{*}{ within no arrears } & 0.264 & 0.171 & 0.123 & 0.107 \\
\hline & & $(.60)$ & $(.44)$ & $(.37)$ \\
\hline between group & 0.031 & 0.054 & 0.125 & 0.078 \\
\hline $\begin{array}{l}\% \text { Share Between Group Inequality } \\
(\theta=0.5)\end{array}$ & 0.3 & 8.1 & 12.8 & 8.1 \\
\hline $\begin{array}{l}\% \text { Change in inequality accounted } \\
\text { for by between group }\end{array}$ & $\mathrm{N} / \mathrm{a}$ & $\mathrm{N} / \mathrm{a}$ & 22.3 & $\begin{array}{l}59.5 \\
{[10.0]}\end{array}$ \\
\hline Entropy $(\theta=2.0)$ & 0.622 & 0.546 & 0.798 & 0.856 \\
\hline \multirow[t]{2}{*}{ within arrears } & 0.037 & 0.208 & 0.345 & 0.481 \\
\hline & & $(.21)$ & $(.26)$ & $(.39)$ \\
\hline \multirow[t]{2}{*}{ within no arrears } & 0.584 & 0.286 & 0.316 & 0.286 \\
\hline & & $(.89)$ & $(1.01)$ & $(.79)$ \\
\hline between group & 0.001 & 0.052 & 0.137 & 0.089 \\
\hline $\begin{array}{l}\text { \%Share Between Group Inequality } \\
(\theta=2.0)\end{array}$ & 0.2 & 9.4 & 17.2 & 10.4 \\
\hline $\begin{array}{l}\% \text { Change in inequality accounted } \\
\text { for by between group }\end{array}$ & $\mathrm{N} / \mathrm{a}$ & $\mathrm{N} / \mathrm{a}$ & 34.1 & $\begin{array}{l}-82.8 \\
{[11.9]}\end{array}$ \\
\hline$\%$ in Arrears & 9.1 & 48.7 & 66.3 & 71.7 \\
\hline
\end{tabular}

Note. Figure in square brackets in column 5 give the change of between-group shares from 1994 to 1998 . Figures in round brackets give within-group weights. 
William Davidson Institute Working Paper 421

Table 3. Counterfactual Real Wage Distributions

\begin{tabular}{|c|c|c|c|c|c|c|c|c|c|}
\hline & Mean & $\begin{array}{l}90^{\text {th }} \\
\text { Pctile }\end{array}$ & Median & $\begin{array}{l}10^{\text {th }} \\
\text { pctile }\end{array}$ & $90 / 10$ & $90 / 50$ & $50 / 10$ & $\begin{array}{l}\text { Coef. } \\
\text { Var. }\end{array}$ & Gini \\
\hline \multicolumn{10}{|l|}{1994} \\
\hline Actual & 609 & 1500 & 422 & 0 & $\mathrm{~N} / \mathrm{a}$ & 3.55 & $\mathrm{~N} / \mathrm{a}$ & 1.08 & 0.546 \\
\hline OLS I & 793 & 1500 & 665 & 210 & 7.14 & 2.25 & 3.17 & 0.73 & 0.380 \\
\hline OLS II & 800 & 1689 & 644 & 150 & 11.26 & 2.62 & 4.29 & 0.83 & 0.447 \\
\hline Heckit & 818 & 1719 & 662 & 156 & 11.01 & 2.59 & 4.24 & 0.81 & 0.438 \\
\hline JMP & 794 & 1655 & 618 & 186 & 8.89 & 2.68 & 3.32 & 0.84 & 0.424 \\
\hline DFL & 788 & 1687 & 582 & 178 & 9.48 & 2.89 & 3.27 & 0.84 & 0.426 \\
\hline $\begin{array}{l}\text { PS I } \\
1996\end{array}$ & 802 & 1562 & 631 & 253 & 6.17 & 2.48 & 2.49 & 0.69 & 0.359 \\
\hline Actual & 500 & 1376 & 287 & 0 & N/a & 4.79 & N/a & 1.32 & 0.636 \\
\hline OLS I & 830 & 1452 & 739 & 262 & 5.54 & 1.96 & 2.82 & 0.66 & 0.342 \\
\hline OLS II & 841 & 1743 & 727 & 124 & 14.05 & 2.39 & 5.86 & 0.84 & 0.457 \\
\hline Heckit & 919 & 1880 & 803 & 172 & 10.93 & 2.34 & 4.67 & 0.77 & 0.423 \\
\hline JMP & 830 & 1720 & 619 & 229 & 7.51 & 2.78 & 2.70 & 0.85 & 0.410 \\
\hline DFL & 817 & 1720 & 585 & 184 & 9.35 & 2.94 & 3.18 & 0.85 & 0.419 \\
\hline PS I & 749 & 1465 & 583 & 223 & 6.57 & 2.51 & 2.61 & 0.79 & 0.395 \\
\hline \multicolumn{10}{|l|}{1998} \\
\hline Actual & 371 & 907 & 206 & 0 & $\mathrm{~N} / \mathrm{a}$ & 4.40 & $\mathrm{~N} / \mathrm{a}$ & 1.33 & 0.618 \\
\hline OLS I & 580 & 1030 & 500 & 167 & 6.17 & 2.06 & 2.99 & 0.75 & 0.367 \\
\hline OLS II & 590 & 1291 & 484 & 66 & 19.56 & 2.66 & 7.33 & 0.94 & 0.503 \\
\hline Heckit & 634 & 1356 & 533 & 91 & 14.90 & 2.54 & 5.85 & 0.88 & 0.471 \\
\hline JMP & 580 & 1209 & 423 & 136 & 8.89 & 2.85 & 3.11 & 0.95 & 0.442 \\
\hline DFL & 571 & 1210 & 417 & 121 & 10.00 & 2.94 & 3.40 & 0.95 & 0.442 \\
\hline PS I & 577 & 1124 & 434 & 158 & 7.11 & 2.59 & 2.75 & 0.85 & 0.405 \\
\hline
\end{tabular}

Source: RLMS. Note: OLS I is OLS estimate without residuals, OLS II includes residuals, PS I is estimate based on propensity score without conditioning on pre-treatment history. 
William Davidson Institute Working Paper 421

Table 4. Counterfactual Real Wage Distributions, 1996

\begin{tabular}{lllllllllll}
\hline & Actual & $\begin{array}{l}\text { No } \\
\text { Arrears }\end{array}$ & OLS I & OLS II & Heckit & JMP & DFL & Match. & PS I & PS II \\
\hline Mean & 510 & 839 & 820 & 814 & 886 & 819 & 813 & 798 & 825 & 807 \\
$90^{\text {th }}$ & 1284 & 1720 & 1405 & 1720 & 1740 & 1720 & 1720 & 1641 & 1720 & 1720 \\
$50^{\text {th }}$ & 322 & 635 & 732 & 688 & 782 & 609 & 608 & 596 & 648 & 596 \\
$10^{\text {th }}$ & 0 & 225 & 268 & 122 & 172 & 229 & 195 & 225 & 229 & 206 \\
$90 / 10$ & n/a & 7.64 & 5.24 & 14.09 & 10.11 & 7.51 & 8.82 & 7.29 & 7.51 & 8.35 \\
$90 / 50$ & 3.99 & 2.71 & 1.92 & 2.50 & 2.22 & 2.82 & 2.83 & 2.75 & 2.65 & 2.88 \\
$50 / 10$ & n/a & 2.82 & 2.73 & 5.64 & 4.54 & 2.66 & 3.11 & 2.64 & 2.83 & 2.89 \\
Coef. Var & 1.26 & 0.81 & 0.65 & 0.83 & 0.76 & 0.83 & 0.83 & 0.83 & 0.79 & 0.83 \\
Gini & 0.621 & 0.411 & 0.336 & 0.449 & 0.416 & 0.403 & 0.411 & 0.407 & 0.402 & 0.417 \\
\hline
\end{tabular}

Source: RLMS. Notes. See Table 3. PS II is estimate based on propensity score conditioning on pre-treatment history. Sample size $=2538$, of which 1351 are in arrears and 1187 are paid in full and on time.

Table 5. Comparing the Gender Wage Ratio, (1996)

$\begin{array}{llllllll}\text { Actual No } & \text { OLS I } & \text { OLS } & \text { Heckit JMP } & \text { DFL } & \text { Match } & \text { PS I } & \text { PS II }\end{array}$
Arrears II

\begin{tabular}{lclllrrrrrl}
\hline Men & & & & & & & & & \\
Mean & 569 & 1013 & 972 & 967 & 1051 & 972 & 949 & 970 & 918 & 887 \\
Median & 337 & 803 & 917 & 898 & 980 & 737 & 788 & 745 & 749 & 683 \\
$90^{\text {th }}$ & 1490 & 2199 & 1562 & 1865 & 1984 & 1973 & 1950 & 2178 & 1950 & 1950 \\
$10^{\text {th }}$ & 0 & 287 & 344 & 225 & 268 & 350 & 241 & 305 & 229 & 229 \\
Women & & & & & & & & & & \\
Mean & 462 & 716 & 693 & 698 & 761 & 693 & 697 & 662 & 748 & 741 \\
Median & 310 & 539 & 605 & 575 & 642 & 526 & 516 & 520 & 563 & 563 \\
$90^{\text {th }}$ & 1147 & 1464 & 1212 & 1515 & 1620 & 1376 & 1456 & 1311 & 1548 & 1577 \\
$10^{\text {th }}$ & 0 & 195 & 229 & 108 & 145 & 191 & 178 & 185 & 212 & 195 \\
Ratio & & & & & & & & & & \\
Mean & 0.81 & 0.71 & 0.71 & 0.72 & 0.72 & 0.71 & 0.73 & 0.68 & 0.81 & 0.84 \\
$50^{\text {th }}$ & 0.92 & 0.67 & 0.66 & 0.64 & 0.66 & 0.71 & 0.65 & 0.70 & 0.75 & 0.82 \\
$90^{\text {th }}$ & 0.77 & 0.67 & 0.78 & 0.81 & 0.82 & 0.70 & 0.75 & 0.60 & 0.79 & 0.80 \\
$10^{\text {th }}$ & n/a & 0.68 & 0.66 & 0.48 & 0.54 & 0.55 & 0.74 & 0.61 & 0.93 & 0.85 \\
\hline
\end{tabular}

Source: RLMS. Sample size $=2538$, of which 1153 are male and 1385 female. 
William Davidson Institute Working Paper 421

Table 6. Comparing Education Wage Ratios, (1996)

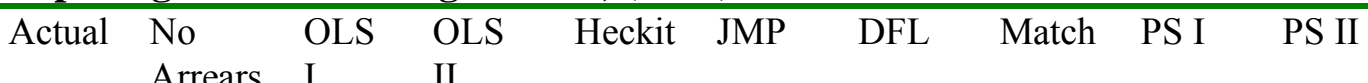
Arrears I II

\begin{tabular}{|c|c|c|c|c|c|c|c|c|c|c|}
\hline \multicolumn{11}{|l|}{ Upper } \\
\hline Mean & 600 & 903 & 900 & 910 & 969 & 900 & 902 & 886 & 860 & 853 \\
\hline Median & 401 & 688 & 792 & 802 & 859 & 688 & 688 & 688 & 675 & 631 \\
\hline \multicolumn{11}{|c|}{ Intermed } \\
\hline Mean & 436 & 779 & 749 & 786 & 870 & 749 & 760 & 729 & 807 & 780 \\
\hline Median & 229 & 597 & 687 & 688 & 767 & 573 & 573 & 563 & 642 & 573 \\
\hline \multicolumn{11}{|l|}{ Low } \\
\hline Mean & 434 & 760 & 757 & 722 & 804 & 757 & 709 & 709 & 776 & 751 \\
\hline Median & 229 & 470 & 676 & 581 & 675 & 573 & 459 & 458 & 573 & 563 \\
\hline \multicolumn{11}{|l|}{ Ratio: } \\
\hline Low & & & & & & & & & & \\
\hline $\begin{array}{l}\text { Mean } \\
\text { upper }\end{array}$ & 1.38 & 1.19 & 1.19 & 1.26 & 1.21 & 1.19 & 1.27 & 1.25 & 1.11 & 1.14 \\
\hline Inter & 1.01 & 1.03 & 0.99 & 1.09 & 1.08 & 0.99 & 1.07 & 1.03 & 1.04 & 1.04 \\
\hline $\begin{array}{l}\text { Median } \\
\text { upper }\end{array}$ & 1.75 & 1.46 & 1.17 & 1.38 & 1.27 & 1.20 & 1.49 & 1.50 & 1.18 & 1.12 \\
\hline Inter & 1.00 & 1.27 & 1.02 & 1.18 & 0.54 & 1.00 & 1.25 & 1.23 & 1.12 & 1.02 \\
\hline
\end{tabular}

Source: RLMS. Sample size=2538, of which 1157 are upper, 888 intermediate and 493 lower.

Table 7. Comparing Regional Wage Ratios, (1996)

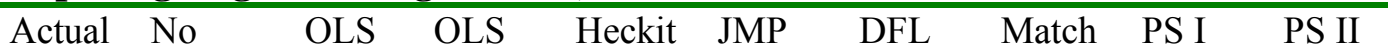
Arrears I II

\begin{tabular}{|c|c|c|c|c|c|c|c|c|c|c|}
\hline $\begin{array}{l}\text { Metro. } \\
\text { Mean }\end{array}$ & 758 & 1027 & 1036 & 1042 & 1094 & 1036 & 906 & 1002 & 923 & 924 \\
\hline $\begin{array}{l}\text { Median } \\
\text { Urals }\end{array}$ & 563 & 803 & 945 & 917 & 962 & 788 & 802 & 803 & 788 & 688 \\
\hline Mean & 630 & 1305 & 1213 & 1253 & 1346 & 1213 & 1270 & 1176 & 1132 & 982 \\
\hline $\begin{array}{l}\text { Median } \\
\text { Other }\end{array}$ & 189 & 1032 & 1130 & 1146 & 1296 & 940 & 963 & 705 & 844 & 642 \\
\hline Mean & 439 & 734 & 719 & 727 & 802 & $\begin{array}{l}719 \\
563\end{array}$ & 716 & 715 & 763 & $\begin{array}{l}758 \\
573\end{array}$ \\
\hline $\begin{array}{l}\text { Median } \\
\text { Ratio: } \\
\text { Other }\end{array}$ & 275 & 573 & 655 & 642 & 688 & 563 & 513 & & & \\
\hline $\begin{array}{l}\text { Mean } \\
\text { Metro }\end{array}$ & 1.73 & 1.40 & 1.44 & 1.43 & 1.36 & 1.44 & 1.27 & 1.40 & 1.11 & 1.22 \\
\hline Urals & 1.44 & 1.80 & 1.69 & 1.72 & 1.68 & 1.69 & 1.77 & 1.64 & 1.04 & 1.30 \\
\hline $\begin{array}{l}\text { Median } \\
\text { Metro }\end{array}$ & 2.05 & 1.40 & 1.44 & 1.43 & 1.40 & 1.40 & 1.56 & 1.41 & 1.18 & 1.20 \\
\hline Urals & 0.69 & 1.80 & 1.73 & 1.79 & 1.88 & 1.67 & 1.69 & 1.24 & 1.12 & 1.12 \\
\hline
\end{tabular}

Source: RLMS. Sample size $=2538$, of which 427 are metropolitan, 241Urals and 1871 other. 
William Davidson Institute Working Paper 421

Table 8. Comparing Industry Wage Ratios, (1996)

$\begin{array}{llllllll}\text { Actual No } & \text { OLS I } & \text { OLS } & \text { Heckit JMP } & \text { DFL } & \text { Match } & \text { PS I } & \text { PS II }\end{array}$

Arrears II

\begin{tabular}{|c|c|c|c|c|c|c|c|c|c|c|}
\hline \multicolumn{11}{|l|}{$\begin{array}{l}\text { Product } \\
\text { ion }\end{array}$} \\
\hline Mean & 527 & 886 & 853 & 874 & 965 & 852 & 839 & 845 & 843 & 829 \\
\hline Median & 271 & 681 & 788 & 756 & 863 & 624 & 596 & 653 & 676 & 608 \\
\hline $10^{\text {th }}$ & 0 & 229 & 275 & 130 & 212 & 251 & 206 & 229 & 229 & 229 \\
\hline $90^{\text {th }}$ & 1261 & 1834 & 1452 & 1945 & 1970 & 1720 & 1720 & 1720 & 1720 & 1834 \\
\hline \multicolumn{11}{|l|}{ Services } \\
\hline Mean & 462 & 805 & 788 & 789 & 844 & 788 & 788 & 755 & 808 & 787 \\
\hline Median & 344 & 605 & 688 & 688 & 745 & 596 & 614 & 573 & 630 & 573 \\
\hline $10^{\text {th }}$ & 0 & 206 & 258 & 149 & 169 & 229 & 194 & 225 & 217 & 200 \\
\hline 90th & 1305 & 1689 & 1351 & 1605 & 1689 & 1605 & 1605 & 1463 & 1720 & 1720 \\
\hline \multicolumn{11}{|l|}{ Ratio } \\
\hline Mean & 1.14 & 1.10 & 1.08 & 1.11 & 1.14 & 1.08 & 1.06 & 1.12 & 1.04 & 1.05 \\
\hline $50^{\text {th }}$ & 0.79 & 1.13 & 1.15 & 1.10 & 1.16 & 1.05 & 0.97 & 1.14 & 1.07 & 1.06 \\
\hline $10^{\text {th }}$ & $\mathrm{n} / \mathrm{a}$ & 1.11 & 1.07 & 0.87 & 1.25 & 1.10 & 1.06 & 1.02 & 1.06 & 1.15 \\
\hline 90 th & 0.97 & 1.09 & 1.07 & 1.21 & 1.17 & 1.07 & 1.07 & 1.18 & 1.00 & 1.07 \\
\hline
\end{tabular}

Sample size $=2538$, of which 1227 are production and 1312 services. 
Appendix

Box A1

Exact matching - algorithm and scheme of conditioning on pre-treatment history

\section{Exact matching algorithm}

I. Condition on following possible pre-treatment labour market history:

- employed and fully paid and in xth decile of wage distribution

- unemployed

- inactive

- employed and experiencing wage arrears (WA)

II. Match treated individuals to individuals with same pre-treatment history using following observable characteristics:

- gender

- region (4 categories)

- qualifications (6 categories)

- age (maximum allowed difference of 10 years - choose those controls that have the minimum age difference)

Assumption: these variables are not affected by the treatment (WA).

Because treated are more than potential controls, matching is done with replacement.

III. Assign wage of matched control to treated individual, or assign average of wages of matched controls

Scheme of Conditioning on pre-treatment history by example

\section{Pre-treatment period}

Potential Control 1 in 95

Employed and fully paid and in

$2^{\text {nd }}$ decile of wage distribution

\section{Treated 1 in 95}

Employed and fully paid and in

$2^{\text {nd }}$ decile of wage distribution

Potential Control 2 in 95

Unemployed

Treated 2 in 95

Unemployed $\underline{\text { Treatment period }}$

Potential Control 1 in 96

Employed and fully paid

Treated 1 in 96

In wage arrears

Potential Control 2 in 96

Employed and fully paid

Treated 2 in 96

In wage arrears 
William Davidson Institute Working Paper 421

Table A1. OLS Real Weekly Wage Estimates

\begin{tabular}{|c|c|c|c|c|c|c|}
\hline & & & & & & 98 \\
\hline & No Arrears & Arrears & No Arrears & Arrears & No Arrears & Arrears \\
\hline Female & -328.844 & -82.797 & -333.160 & -40.009 & -233.198 & -66.771 \\
\hline & $(24.318)^{* *}$ & $(28.675)^{* *}$ & $(36.521)^{* *}$ & $(23.981)$ & $(25.946)^{* *}$ & $(16.803)^{* *}$ \\
\hline Age & 27.947 & 5.922 & 24.714 & 4.414 & 35.168 & 4.891 \\
\hline & $(6.544)^{* *}$ & $(8.201)$ & $(9.800)^{*}$ & $(6.724)$ & $(6.817)^{* *}$ & $(4.694)$ \\
\hline Age2 & -0.389 & -0.092 & -0.367 & -0.069 & -0.449 & -0.093 \\
\hline & $(0.077)^{* *}$ & $(0.098)$ & $(0.116)^{* *}$ & $(0.080)$ & $(0.081)^{* *}$ & $(0.056)$ \\
\hline University & 379.099 & 112.386 & 243.810 & 91.789 & 266.344 & 140.187 \\
\hline & $(37.974)^{* *}$ & $(46.869)^{*}$ & $(54.541)^{* *}$ & $(36.136)^{*}$ & $(41.377)^{* *}$ & $(25.664)^{* *}$ \\
\hline Technical & 190.469 & 2.117 & 69.194 & 54.203 & 57.383 & 47.081 \\
\hline & $(36.510)^{* *}$ & $(42.481)$ & $(52.169)$ & $(33.435)$ & $(40.152)$ & (24.389) \\
\hline PTU 1 & 49.374 & -43.377 & -117.411 & -24.110 & -38.326 & 2.641 \\
\hline & $(40.950)$ & $(45.926)$ & $(61.551)$ & (37.010) & $(44.640)$ & $(26.754)$ \\
\hline PTU 2 & 29.637 & -66.157 & -34.488 & 45.818 & -105.285 & -1.476 \\
\hline & $(47.106)$ & $(53.921)$ & $(72.830)$ & $(46.796)$ & $(53.254)^{*}$ & $(30.662)$ \\
\hline Other Quals. & 42.720 & -82.750 & -144.592 & -48.117 & -14.694 & 45.585 \\
\hline & $(42.341)$ & $(47.680)$ & $(66.053)^{*}$ & $(36.181)$ & $(48.155)$ & $(28.830)$ \\
\hline North West & 83.355 & -248.990 & -74.875 & -283.137 & 118.066 & -116.845 \\
\hline & $(51.778)$ & $(73.535)^{* *}$ & $(78.128)$ & $(65.712)^{* *}$ & $(57.282)^{*}$ & $(48.022)^{*}$ \\
\hline Central & -265.516 & -306.965 & -311.085 & -318.211 & -179.586 & -218.597 \\
\hline & $(39.265)^{* *}$ & $(63.264)^{* *}$ & $(57.314)^{* *}$ & $(60.239)^{* *}$ & $(42.953)^{* *}$ & $(43.774)^{* *}$ \\
\hline Volga & -368.290 & -311.739 & -474.672 & -440.988 & -215.499 & -251.302 \\
\hline & $(40.676)^{* *}$ & $(62.459)^{* *}$ & $(61.497)^{* *}$ & $(59.326)^{* *}$ & $(45.960)^{* *}$ & $(43.270)^{* *}$ \\
\hline Caucasus & -308.003 & -339.224 & -313.739 & -399.983 & -205.358 & -260.768 \\
\hline & $(45.716)^{* *}$ & $(65.725)^{* *}$ & $(69.570)^{* *}$ & $(61.104)^{* *}$ & $(50.731)^{* *}$ & $(46.063)^{* *}$ \\
\hline Urals & -190.510 & -185.588 & -273.558 & -228.785 & -189.485 & -181.967 \\
\hline & $(41.643)^{* *}$ & $(64.530)^{* *}$ & $(62.013)^{* *}$ & $(59.346)^{* *}$ & $(46.324)^{* *}$ & $(44.090)^{* *}$ \\
\hline Western Siberia & 198.770 & -247.740 & 189.993 & -337.197 & 230.365 & -193.010 \\
\hline & $(48.672)^{* *}$ & $(68.635)^{* *}$ & $(73.810)^{*}$ & $(62.005)^{* *}$ & $(56.277)^{* *}$ & $(46.780)^{* *}$ \\
\hline East & 82.152 & -190.736 & -133.817 & -363.395 & -22.999 & -191.335 \\
\hline & $(48.010)$ & $(66.243)^{* *}$ & $(83.308)$ & $(61.224)^{* *}$ & $(54.385)$ & $(45.698)^{* *}$ \\
\hline State & -86.539 & -34.385 & -178.204 & -27.526 & -117.536 & -58.777 \\
\hline & $(25.128)^{* *}$ & $(29.600)$ & $(39.320)^{* *}$ & $(24.746)$ & $(27.499)^{* *}$ & $(17.230)^{* *}$ \\
\hline Agriculture & -250.863 & -97.303 & -251.971 & -60.974 & -169.516 & -111.494 \\
\hline & $(59.234)^{* *}$ & $(54.806)$ & $(95.687)^{* *}$ & $(52.865)$ & $(57.422)^{* *}$ & $(32.569)^{* *}$ \\
\hline Manufacturing & -11.362 & 15.018 & 46.962 & 46.869 & -93.825 & -35.587 \\
\hline & $(45.083)$ & $(52.705)$ & $(71.786)$ & $(51.275)$ & $(44.513)^{*}$ & $(29.455)$ \\
\hline Construction & 257.273 & 282.506 & 291.500 & 174.120 & 75.914 & -23.680 \\
\hline & $(57.922)^{* *}$ & $(62.508)^{* *}$ & $(98.849)^{* *}$ & $(62.138)^{* *}$ & $(68.167)$ & (38.384) \\
\hline Energy & 260.745 & 1.952 & 441.998 & 244.459 & 146.231 & 92.060 \\
\hline & $(52.590)^{* *}$ & $(70.162)$ & $(85.853)^{* *}$ & $(58.332)^{* *}$ & $(52.746)^{* *}$ & $(34.916)^{* *}$ \\
\hline Transport & 232.231 & 38.041 & 300.775 & 91.000 & 71.933 & 105.861 \\
\hline & $(52.218)^{* *}$ & $(63.508)$ & $(81.381)^{* *}$ & $(60.297)$ & $(50.453)$ & $(36.463)^{* *}$ \\
\hline Retail & 41.109 & 234.521 & 30.394 & 152.660 & 76.558 & 58.465 \\
\hline & $(51.443)$ & $(72.558)^{* *}$ & (78.304) & $(67.108)^{*}$ & $(49.225)$ & $(44.084)$ \\
\hline Finance & 383.194 & 729.191 & 457.864 & 427.141 & 131.729 & 111.311 \\
\hline & $(94.452)^{* *}$ & $(187.211)^{* *}$ & $(122.168)^{* *}$ & $(215.898)^{*}$ & $(84.225)$ & (100.764) \\
\hline Health/Education & -65.742 & 79.929 & 28.073 & -19.806 & -92.157 & -20.960 \\
\hline & $(42.608)$ & $(55.645)$ & (69.499) & $(49.456)$ & $(41.488)^{*}$ & (28.996) \\
\hline Firm size $11-50$ & -9.312 & 11.026 & 27.490 & -0.066 & 83.296 & -69.379 \\
\hline & $(47.472)$ & $(57.127)$ & (73.808) & $(53.442)$ & $(55.176)$ & $(37.761)$ \\
\hline Firm size $51-100$ & 13.184 & 54.215 & -12.727 & 46.439 & 40.027 & -28.619 \\
\hline & $(53.774)$ & $(64.810)$ & $(83.160)$ & $(58.747)$ & $(60.579)$ & $(41.245)$ \\
\hline
\end{tabular}


William Davidson Institute Working Paper 421

\begin{tabular}{lllllll}
\hline Firm size 101-500 & 78.130 & 109.737 & 47.045 & 62.613 & 66.823 & -19.890 \\
& $(48.484)$ & $(57.951)$ & $(76.932)$ & $(53.216)$ & $(58.393)$ & $(37.207)$ \\
Firm size 501-1000 & 177.653 & 189.683 & 86.523 & 59.353 & 293.726 & -6.018 \\
& $(51.093)^{* *}$ & $(60.095)^{* *}$ & $(80.915)$ & $(57.817)$ & $(60.541)^{* *}$ & $(39.212)$ \\
Firm size missing & 55.855 & 37.957 & 2.156 & -27.662 & 93.407 & -22.801 \\
& $(48.708)$ & $(58.531)$ & $(70.627)$ & $(52.176)$ & $(55.107)$ & $(36.204)$ \\
Job Tenure 1-2 yrs & 50.552 & -15.643 & 99.058 & 53.044 & 61.998 & 33.746 \\
& $(40.085)$ & $(50.518)$ & $(63.362)$ & $(43.535)$ & $(43.738)$ & $(28.735)$ \\
2-5 yrs & -44.714 & 12.982 & 184.181 & 66.827 & 72.079 & 32.913 \\
& $(35.527)$ & $(43.460)$ & $(54.085)^{* *}$ & $(37.186)$ & $(38.963)$ & $(24.867)$ \\
$5-10$ yrs & -14.406 & -15.183 & 125.330 & 25.428 & 73.904 & 62.436 \\
& $(39.176)$ & $(45.520)$ & $(60.085)^{*}$ & $(38.875)$ & $(42.646)$ & $(26.842)^{*}$ \\
$10-20$ yrs & 25.448 & -3.080 & 120.659 & 13.702 & 99.791 & 56.950 \\
& $(38.021)$ & $(45.063)$ & $(60.814)^{*}$ & $(37.612)$ & $(45.074)^{*}$ & $(27.370)^{*}$ \\
20 yrs+ & 112.283 & -32.667 & 159.724 & 62.463 & 102.873 & 113.582 \\
& $(44.758)^{*}$ & $(52.423)$ & $(68.120)^{*}$ & $(42.388)$ & $(50.534)^{*}$ & $(30.381)^{* *}$ \\
Constant & 470.968 & 412.070 & 727.343 & 401.153 & 33.770 & 350.394 \\
& $(142.358)^{* *}$ & $(181.035)^{*}$ & $(206.173)^{* *}$ & $(155.882)^{*}$ & $(152.983)$ & $(107.224)^{* *}$ \\
N & & & & & 1669 & 1674 \\
Adjusted R-squared & 0.28 & 1332 & 1368 & 1532 & 0.23 & 0.11 \\
\hline
\end{tabular}


William Davidson Institute Working Paper 421

Table A2. Logit Estimates of Probability of Not Being in Arrears

\begin{tabular}{|c|c|c|c|}
\hline & 1994 & 1996 & 1998 \\
\hline \multirow[t]{2}{*}{ Female } & 0.273 & 0.148 & 0.100 \\
\hline & $(0.078)^{* *}$ & $(0.088)$ & $(0.080)$ \\
\hline \multirow[t]{2}{*}{ Age } & -0.028 & -0.025 & -0.043 \\
\hline & $(0.022)$ & $(0.024)$ & $(0.022)^{*}$ \\
\hline \multirow[t]{2}{*}{ Age2 } & 0.000 & 0.000 & 0.000 \\
\hline & $(0.000)$ & $(0.000)$ & $(0.000)$ \\
\hline \multirow[t]{2}{*}{ University } & -0.110 & 0.358 & 0.266 \\
\hline & $(0.125)$ & $(0.131)^{* *}$ & $(0.125)^{*}$ \\
\hline \multirow[t]{2}{*}{ Technical } & -0.164 & 0.310 & 0.216 \\
\hline & $(0.116)$ & $(0.124)^{*}$ & $(0.120)$ \\
\hline \multirow[t]{2}{*}{ PTU 1} & -0.056 & -0.004 & 0.056 \\
\hline & $(0.127)$ & $(0.142)$ & $(0.133)$ \\
\hline \multirow[t]{2}{*}{ PTU 2} & 0.022 & 0.276 & 0.068 \\
\hline & $(0.147)$ & $(0.173)$ & $(0.155)$ \\
\hline \multirow[t]{2}{*}{ Other Quals. } & 0.030 & -0.149 & 0.221 \\
\hline & $(0.132)$ & $(0.147)$ & $(0.142)$ \\
\hline \multirow[t]{2}{*}{ North West } & -0.810 & -1.205 & -1.206 \\
\hline & $(0.184)^{* *}$ & $(0.208)^{* *}$ & $(0.201)^{* *}$ \\
\hline \multirow[t]{2}{*}{ Central } & -0.446 & -0.616 & -0.745 \\
\hline & $(0.153)^{* *}$ & $(0.176)^{* *}$ & $(0.170)^{* *}$ \\
\hline \multirow[t]{2}{*}{ Volga } & -0.659 & -1.067 & -1.252 \\
\hline & $(0.153)^{* *}$ & $(0.177)^{* *}$ & $(0.173)^{* *}$ \\
\hline \multirow[t]{2}{*}{ Caucasus } & -0.695 & -1.136 & -0.944 \\
\hline & $(0.167)^{* *}$ & $(0.194)^{* *}$ & $(0.191)^{* *}$ \\
\hline \multirow[t]{2}{*}{ Urals } & -0.561 & -1.015 & -1.095 \\
\hline & $(0.157)^{* *}$ & $(0.178)^{* *}$ & $(0.176)^{* *}$ \\
\hline \multirow[t]{2}{*}{ Western Siberia } & -0.826 & -1.264 & -1.270 \\
\hline & $(0.173)^{* *}$ & $(0.196)^{* *}$ & $(0.196)^{* *}$ \\
\hline \multirow[t]{2}{*}{ East } & -0.884 & -1.777 & -1.335 \\
\hline & $(0.169)^{* *}$ & $(0.208)^{* *}$ & $(0.192)^{* *}$ \\
\hline \multirow[t]{2}{*}{ State } & -0.271 & -0.182 & -0.270 \\
\hline & $(0.080)^{* *}$ & $(0.093)^{*}$ & $(0.083)^{* *}$ \\
\hline \multirow[t]{2}{*}{ Agriculture } & -0.760 & -0.716 & -0.383 \\
\hline & $(0.168)^{* *}$ & $(0.221)^{* *}$ & $(0.172)^{*}$ \\
\hline \multirow[t]{2}{*}{ Manufacturing } & -0.382 & -0.401 & -0.582 \\
\hline & $(0.143)^{* *}$ & $(0.180)^{*}$ & $(0.138)^{* *}$ \\
\hline \multirow[t]{2}{*}{ Construction } & -0.530 & -0.462 & -0.617 \\
\hline & $(0.173)^{* *}$ & $(0.232)^{*}$ & $(0.194)^{* *}$ \\
\hline \multirow[t]{2}{*}{ Energy } & 0.319 & -0.230 & -0.202 \\
\hline & $(0.178)$ & $(0.208)$ & $(0.161)$ \\
\hline Transport & -0.010 & 0.265 & 0.099 \\
\hline & $(0.168)$ & $(0.207)$ & $(0.162)$ \\
\hline Retail & 0.355 & 0.482 & 0.622 \\
\hline & $(0.184)$ & $(0.216)^{*}$ & $(0.182)^{* *}$ \\
\hline Finance & 0.792 & 1.955 & 1.039 \\
\hline & $(0.434)$ & $(0.564)^{* *}$ & $(0.377)^{* *}$ \\
\hline Health/Education & 0.396 & -0.235 & -0.311 \\
\hline & $(0.143)^{* *}$ & $(0.174)$ & $(0.131)^{*}$ \\
\hline Firm size $11-50$ & 0.045 & -0.048 & 0.297 \\
\hline & $(0.156)$ & $(0.191)$ & $(0.180)$ \\
\hline Firm size $51-100$ & 0.155 & -0.178 & 0.335 \\
\hline & $(0.178)$ & $(0.212)$ & $(0.196)$ \\
\hline Firm size $101-500$ & 0.161 & -0.373 & -0.038 \\
\hline
\end{tabular}


William Davidson Institute Working Paper 421

\begin{tabular}{llll}
\hline & $(0.159)$ & $(0.196)$ & $(0.183)$ \\
Firm size 501-1000 & 0.002 & -0.192 & 0.150 \\
& $(0.167)$ & $(0.209)$ & $(0.193)$ \\
Firm size missing & -0.044 & 0.076 & 0.169 \\
Job Tenure 1-2 yrs & $(0.160)$ & $(0.186)$ & $(0.177)$ \\
& 0.080 & 0.075 & 0.294 \\
$2-5$ yrs & $(0.134)$ & $(0.158)$ & $(0.137)^{*}$ \\
& -0.004 & 0.182 & 0.283 \\
$5-10$ yrs & $(0.117)$ & $(0.134)$ & $(0.120)^{*}$ \\
& -0.180 & 0.026 & 0.270 \\
$10-20$ yrs & $(0.125)$ & $(0.145)$ & $(0.130)^{*}$ \\
& -0.108 & -0.136 & 0.231 \\
20 yrs + & $(0.122)$ & $(0.143)$ & $(0.135)$ \\
& -0.190 & -0.118 & 0.205 \\
loc3 & $(0.143)$ & $(0.160)$ & $(0.151)$ \\
& -0.592 & -0.483 & -0.508 \\
Constant & $(0.100)^{* *}$ & $(0.119)^{* *}$ & $(0.106)^{* *}$ \\
& 2.065 & 1.710 & 1.911 \\
& $(0.480)^{* *}$ & $(0.535)^{* *}$ & $(0.493)^{* *}$ \\
$\mathrm{~N}$ & & & \\
Log L & 3977 & 2899 & 3341 \\
\hline
\end{tabular}


William Davidson Institute Working Paper 421

Table A3. Earnings Mobility in Russia, 1994-98

a) $1994 / 95$

\begin{tabular}{llllll}
\hline Total & & & 1995 & \\
1994 & $1^{\text {st }}$ Quintile & 2 nd Quintile & 3 rd Quintile & 4 th Quintile & $5^{\text {th }}$ Quintile \\
1 & 46.5 & 21.1 & 12.2 & 10.8 & 9.5 \\
2 & 20.9 & 37.8 & 25.3 & 10.6 & 5.1 \\
3 & 17.1 & 22.5 & 31.5 & 21.9 & 7.0 \\
4 & 11.1 & 8.2 & 22.2 & 34.8 & 23.9 \\
5 & 11.0 & 5.2 & 8.2 & 20.7 & 54.8 \\
No Arrears & & & 1995 & & \\
1994 & 1 & 2 & 3 & 4 & 5 \\
1 & & 62.5 & 25.0 & & 12.5 \\
2 & & 49.8 & 33.5 & 10.9 & 5.0 \\
3 & & 21.6 & 41.6 & 29.2 & 7.6 \\
4 & & 4.9 & 24.4 & 43.2 & 27.4 \\
5 & & 1.5 & 6.3 & 23.6 & 68.5 \\
\hline
\end{tabular}

b) $1995 / 96$

\begin{tabular}{llllll}
\hline Total & & & 1996 & & \\
1995 & $1^{\text {st }}$ Quintile & 2nd Quintile & 3rd Quintile & 4 th Quintile & $5^{\text {th }}$ Quintile \\
1 & 58.9 & 8.0 & 14.6 & 11.5 & 7.1 \\
2 & 36.8 & 17.5 & 29.0 & 11.5 & 5.2 \\
3 & 25.1 & 7.9 & 33.8 & 24.2 & 9.0 \\
4 & 21.1 & 2.5 & 20.2 & 32.3 & 24.0 \\
5 & 17.2 & 1.8 & 8.7 & 20.2 & 52.1 \\
No Arrears & & & 1996 & & \\
1995 & 1 & 2 & 3 & 4 & 5 \\
1 & & & & & \\
2 & & 21.3 & 54.6 & 19.4 & 4.6 \\
3 & & 3.0 & 49.4 & 38.1 & 9.5 \\
4 & & 1.0 & 15.4 & 48.0 & 35.6
\end{tabular}


William Davidson Institute Working Paper 421

\section{c) $1995 / 98$}

\begin{tabular}{llllll} 
Total & & & 1998 & \\
1995 & $1^{\text {st }}$ Quintile & 2nd Quintile & 3 rd Quintile & 4 th Quintile & $5^{\text {th }}$ Quintile \\
1 & 41.2 & 17.7 & 18.2 & 13.7 & 8.9 \\
2 & 30.8 & 24.6 & 26.0 & 13.3 & 5.3 \\
3 & 24.9 & 10.8 & 29.7 & 23.9 & 10.8 \\
4 & 19.9 & 7.1 & 17.9 & 31.9 & 23.1 \\
5 & 14.9 & 3.4 & 12.3 & 24.9 & 44.6 \\
No Arrears & & & 1998 & & \\
1995 & 1 & 2 & 3 & 4 & 5 \\
1 & & 50.0 & 16.7 & 33.3 & \\
2 & & 21.1 & 43.7 & 29.6 & 5.6 \\
3 & & 4.5 & 41.4 & 41.4 & 13.8 \\
4 & & 2.6 & 15.7 & 44.4 & 37.8 \\
5 & & 0.9 & 8.9 & 20.5 & 69.6 \\
\hline
\end{tabular}




\section{DAVIDSON INSTITUTE WORKING PAPER SERIES - Most Recent Papers}

The entire Working Paper Series may be downloaded free of charge at: www.wdi.bus.umich.edu

CURRENT AS OF 1/17/02

\begin{tabular}{|c|c|c|}
\hline Publication & Authors & Date \\
\hline No. 421 Wage Arrears and the Distribution of Earnings in Russia & $\begin{array}{l}\text { Hartmut Lehmann and Jonathan } \\
\text { Wadsworth }\end{array}$ & Dec. 2001 \\
\hline $\begin{array}{l}\text { No. } 420 \text { Transferring Collective Knowledge: Collective and Fragmented } \\
\text { Teaching and Learning in the Chinese Auto Industry }\end{array}$ & $\begin{array}{l}\text { Jane Zhou, Jaideep Anand, and } \\
\text { Will Mitchell }\end{array}$ & Dec. 2001 \\
\hline $\begin{array}{l}\text { No. 419: Liberalization, Corporate Governance, and the Performance of } \\
\text { Newly Privatized Firms }\end{array}$ & $\begin{array}{l}\text { Narjess Boubakri, Jean-Claude } \\
\text { Cosset, and Omrane Guedhami }\end{array}$ & Dec. 2001 \\
\hline $\begin{array}{l}\text { No. 418: The European Data Privacy Directive and International } \\
\text { Relations }\end{array}$ & Steven R. Salbu & Dec. 2001 \\
\hline $\begin{array}{l}\text { No. 417: Capital Markets and Capital Allocation: Implications for } \\
\text { Economies in Transition }\end{array}$ & $\begin{array}{l}\text { Artyom Durnev, Randall Morck, } \\
\text { and Bernard Yeung }\end{array}$ & Dec. 2001 \\
\hline $\begin{array}{l}\text { No. 416 Forthcoming in: The Journal of Economic Perspectives, "Data } \\
\text { Watch. Research Data from Transition Economies," 16(2) Feb. } 2002 .\end{array}$ & $\begin{array}{l}\text { Randall K. Filer and Jan } \\
\text { Hanousek }\end{array}$ & Dec. 2001 \\
\hline $\begin{array}{l}\text { No. } 415 \text { Forthcoming in: The Journal of Economic Perspectives, } \\
\text { "Transition Economies: Performance and Challenges," 16(2) Feb. } 2002 .\end{array}$ & Jan Svejnar & Dec. 2001 \\
\hline $\begin{array}{l}\text { No. } 414 \text { Forthcoming in: The Journal of Economic Perspectives, "The } \\
\text { Great Divide and Beyond: Financial Architecture in Transition," 16(2) } \\
\text { Feb. } 2002 \text {. }\end{array}$ & Erik Berglof and Patrick Bolton & Dec. 2001 \\
\hline $\begin{array}{l}\text { No. } 413 \text { Forthcoming in: The Journal of Economic Perspectives, "The } \\
\text { Political Economy of Transition," 16(2) Feb. } 2002 .\end{array}$ & Gérard Roland & Dec. 2001 \\
\hline $\begin{array}{l}\text { No. 412: The Response of Consumption in Russian Households to } \\
\text { Economic Shocks }\end{array}$ & Steven Stillman & Oct. 2001 \\
\hline No. 411: Mark-ups in Hungarian Corporate Sector & László Halpern and Gábor Kőrösi & Aug. 2001 \\
\hline No. 410: Economic Development, Legality, and the Transplant Effect & $\begin{array}{l}\text { Daniel Berkowitz, Katarina } \\
\text { Pistor, Jean-Francois Richard }\end{array}$ & Sept. 2001 \\
\hline No. 409: Development Strategy, Viability, and Economic Convergence & Justin Yifu Lin & Oct. 2001 \\
\hline No. 408: Labor Supply, Informal Economy and Russian Transition & Maxim Bouev & May 2001 \\
\hline No. 407: Corporate Governance in China: Then and Now & Cindy Schipani and Liu Junhai & Nov. 2001 \\
\hline No. 406: Entrepreneurship and Post-Socialist Growth & $\begin{array}{l}\text { Daniel Berkowitz and David N. } \\
\text { DeJong }\end{array}$ & Oct. 2001 \\
\hline $\begin{array}{l}\text { No. } 405 \text { Forthcoming in: European Economic Review, "Policy Reform } \\
\text { and Growth in Post-Soviet Russia." }\end{array}$ & $\begin{array}{l}\text { Daniel Berkowitz and David N. } \\
\text { DeJong }\end{array}$ & Oct. 2001 \\
\hline $\begin{array}{l}\text { No. 404: Social Policies and Structures: Institutional Frictions and Traps } \\
\text { in the Czech Republic after } 1989\end{array}$ & Jiří Večerník & Nov. 2001 \\
\hline $\begin{array}{l}\text { No. 403: Investment, Efficiency, and Credit Rationing: Evidence from } \\
\text { Hungarian Panel Data }\end{array}$ & Mathilde Maurel & Nov. 2001 \\
\hline $\begin{array}{l}\text { No. 402: Subduing High Inflation in Romania. How to Better Monetary } \\
\text { and Exchange Rate Mechanisms? }\end{array}$ & $\begin{array}{l}\text { Daniel Daianu and Radu } \\
\text { Vranceanu }\end{array}$ & Aug. 2001 \\
\hline $\begin{array}{l}\text { No. 401: The Gender Wage Gap in Bulgaria: A Semiparametric } \\
\text { Estimation of Discrimination }\end{array}$ & Dean Jolliffe & July 2001 \\
\hline $\begin{array}{l}\text { No. 400: Do External Auditors Perform a Corporate Governance Role in } \\
\text { Emerging Markets? Evidence from East Asia }\end{array}$ & Joseph P. H. Fan and T.J. Wong & Oct. 2001 \\
\hline $\begin{array}{l}\text { No. 399: Financial Conditions and Investment during the Transition: } \\
\text { Evidence from Czech Firms }\end{array}$ & Lubomír Lízal and Jan Svejnar & Oct. 2001 \\
\hline $\begin{array}{l}\text { No. 398: Accessible Pareto-Improvements: Using Market Information to } \\
\text { Reform Inefficiencies }\end{array}$ & Michael Mandler & May 2001 \\
\hline No. 397: The Making of an Integrated National Grain Market in China & Wubiao Zhou & Oct. 2001 \\
\hline No. 396: Corruption and Resource Allocation: Evidence from China & Wei Li & June 2001 \\
\hline $\begin{array}{l}\text { No. 395: Government Shareholding and the Value of China's Modern } \\
\text { Firms }\end{array}$ & Lihui Tian & Apr. 2001 \\
\hline
\end{tabular}

